\title{
Do banks and industrial companies have equal access to reputable underwriters in debt markets?
}

Carbo-Valverde, Santiago; Cuadros Solas, Pedro; Rodríguez-Fernández, Francisco

\section{Journal of Corporate Finance}

DOI:

10.1016/j.jcorpfin.2017.04.015

Published: 01/08/2017

Peer reviewed version

Cyswllt i'r cyhoeddiad / Link to publication

Dyfyniad o'r fersiwn a gyhoeddwyd / Citation for published version (APA):

Carbo-Valverde, S., Cuadros Solas, P., \& Rodríguez-Fernández, F. (2017). Do banks and industrial companies have equal access to reputable underwriters in debt markets? Journal of Corporate Finance, 45, 176-202. https://doi.org/10.1016/j.jcorpfin.2017.04.015

\footnotetext{
Hawliau Cyffredinol / General rights

Copyright and moral rights for the publications made accessible in the public portal are retained by the authors and/or other copyright owners and it is a condition of accessing publications that users recognise and abide by the legal requirements associated with these rights.

- Users may download and print one copy of any publication from the public portal for the purpose of private study or research.

- You may not further distribute the material or use it for any profit-making activity or commercial gain

- You may freely distribute the URL identifying the publication in the public portal ?
}

Take down policy

If you believe that this document breaches copyright please contact us providing details, and we will remove access to the work immediately and investigate your claim. 


\title{
Do banks and industrial companies have equal access to reputable underwriters in debt markets?
}

\author{
Santiago Carbó-Valverde ${ }^{1}$ \\ (s.carbo-valverde@bangor.ac.uk) \\ Francisco Rodriguez-Fernandez ${ }^{2}$ \\ (franrod@ugr.es) \\ Pedro J. Cuadros-Solas ${ }^{2}$ \\ (pjcuadros@ugr.es)
}

We analyze whether banks and industrial companies have equal access to debt markets through reputable underwriters and explore the determinants of that matching for both types of firms. Using a sample of European corporate bonds during the years 2003-2013, we find that the odds of matching with a reputable underwriter were about 1.5 times greater for nonfinancial companies than for banks. The odds of matching with a reputable underwriter were 10.92 times lower for a bank during the crisis. As for the determinants of the matching probability, the marginal effect of the bond size on the matching probability is 1.70 larger for non-financial firms than for banks. Furthermore, the effect of bond size is greater for large non-financial companies than for large banks while the effect of maturity is larger for banks than for non-financial companies.

Keywords: Underwriter reputation, corporate bonds, asymmetries, banks, underwriting

JEL Classification: G32, G2

1

Bangor Business School

Hen Goleg, College Road, Bangor,

LL57 2DG

Bangor (Wales, UK)

2

Departamento de Teoría e Historia Económica

Facultad de CC.Económicas y Empresariales

Universidad de Granada

Campus Cartuja s/n, 18071 - Granada (España) 


\section{INTRODUCTION}

The success of a debt issuance offering depends largely on the ability to solve information asymmetries in the placement of the issues among investors. This process comprises issuers, banks and investors, and goes further than a selling mechanism. Investment and commercial banks appointed as underwriters perform research, information production, marketing and market stabilization activities, among others. ${ }^{1}$

A large body of literature highlights the relevance of underwriters as financial intermediaries able to reduce the asymmetric information problems between issuers and investors. These information asymmetries turn underwriting into a market for external certification services since underwriters provide an enhanced worthwhile external certification (Duarte-Silva, 2010). While a certain degree of information asymmetry explains the role of underwriters in financial markets, prior literature underlines the twofold role of reputation. Seminal theoretical papers emphasize the role of underwriter reputation on capital and debt raising, arguing that the reputation of financial intermediaries is able to reduce more efficiently the asymmetric information problems between issuers and investors (Beatty and Ritter, 1986; Booth and Smith, 1986; Carter and Manaster, 1990; Chemmanur and Fulghieri, 1994). Furthermore, it has been shown that a reputation acquisition process is generated when banks place deals into primary markets. Neupane and Thapa (2013) analyze the investorunderwriter relationship and show that prestigious underwriters hold strong relations with institutional investors. Issuers aim to match with a reputable underwriter and underwriters want to place issues from high-quality issuers. A number of studies have agreed on reputation

\footnotetext{
${ }^{1}$ The placement of debt issues in primary markets has changed from the "bought deal" to "best effort". In the "bought deal" method, the bank in charge of the placement commits to buy the bond to afterwards resell it. This method provides greater guarantees to the issuer but it adds risk to the bank. The "bought deal" method has progressively lost ground. During $2003-$ 2013 Dealogic reports that $94 \%$ of the corporate bonds placed in Europe were made on a "best effort" basis. With this method, no additional guarantees are provided to the issuer but the bank in charge of the placement does not act as a mere distributor because it also provides certification, screening and marketing. When the "bought deal" was the preferred choice in debt markets, the bank in charge of the placement was referred to as "underwriter". When the placement is made on a "best effort" basis the bank managing the placement is the "bookrunner". Currently, the expression "lead underwriter" and "underwriter" are used indistinctly in the U.S., whereas in London "underwriter" continues to be used, although the method chosen is "at the best efforts". For comparative purposes and given its extensive usage, we will refer to debt placement as underwriting.
} 
being relevant to the matching for one of the sides (Benveniste et al., 2003; Drucker and Puri, 2005; Hoberg, 2007; Kanatas and Qi, 2003; Ljungqvist et al., 2006; Yasuda, 2007), or for both sides (Fernando et al,. 2015; Fernando et al., 2012).

While a number of prior studies have been devoted to assessing the issuer-underwriter reputational matching and its main determinants in non-financial deals, the evidence is mostly confined to equity deals issued in the U.S. capital markets. This paper investigates the issuerreputable underwriter matching process in corporate debt issuance by both banks and industrial companies. We address the question of whether banks and industrial companies have equal access to external certification through reputable underwriters.

Although banks are more frequent bond issuers, the corporate finance literature focuses on non-financial firms, assuming that banks are not in need of acquiring external certification. However, as shown by Hirtle (2006) there are positive price and quantity effects for banks when they access external certification. Importantly, the need for external certification by banks has been increasing over time and it has been mainly achieved through a third-party underwriter rather than by self-underwriting. Hence, excluding banks from the analysis - as in most of the earlier studies - implies that a significant portion of the external certification market is ignored ${ }^{2}$. Although we control for self-underwritten deals in our regressions, the determinants of self-underwritten deals are not specifically examined in this paper as they do not represent the external certification provided by third-party underwriters.

As being matched with a reputable underwriter determines the final conditions obtained on the issuance, a differential access to a reputable underwriter is a matter of importance. The superior certification provided by reputable underwriters turns the issue into a high-quality external certification. In this sense, Fang (2005) empirically finds that reputable banks obtain higher prices (lower yields) for their issuers, concluding that reputable

\footnotetext{
${ }^{2}$ A seminal paper on underwriting by Gande et al. (1999) states that the rationale for excluding financial firms is due to a historical reliance on negotiated rather than competitive underwritings for these firms. However, nowadays the investment industry has evolved into a more competitive industry, as the changes in league tables reflect.
} 
underwriters are able to offer their clients services of superior quality. In a similar vein, Fernando, Gatchev, May, \& Megginson, (2015) document the incremental benefits that issuers firms receive from high-reputation underwriting. Therefore, due to this superior external certification coupled with the higher net proceeds provided, issuers asking for external certification - banks and non-banks - would in principle benefit more from external certification by matching a reputable underwriter. Moreover, as Chemmanur \& Fulghieri (1994), Duarte-Silva (2010) and Puri (1996) suggest, all kind of issuers (banks and nonfinancial firms) seek certification.

A large number of studies have underlined the "specialness" of banks in producing and handling information in financial markets (Allen and Faulhaber, 1988; Allen and Gale, 1997; Baron, 1982; Booth and Smith, 1986; Dewatripont and Maskin, 1995; Diamond, 1984, 1991; Grinblatt and Hwang, 1989; Leland and Pyle, 1977; Welch, 1989). However, banks' informational advantage is related to their ability to assess the creditworthiness of nonfinancial firms, while the matching of issuers and underwriters has to do with external certification. Differences in opaqueness between banks and non-financial firms may explain the need for external certification. As shown by Flannery et al. (2013), banks are not qualitatively more opaque than matched nonfinancial firms during normal periods, but they are significantly more opaque during crisis periods. This relatively larger opaqueness of banks compared to non-financial firms during times of financial stress would suggest that banks were less likely to obtain a high-quality external certification during a banking crisis but no significant differences should be found in other periods.

Our analysis relies on a sample of 3,687 corporate bonds issued during 2003-2013. Furthermore, we aim to complement a strand of the literature that has investigated the determinants of reputable matching by empirically quantifying what characteristics of the bond structure and issuer characteristics are the most relevant. From a methodological perspective, as in other studies, we use the market share as a proxy for underwriter reputation. 
However, we take into consideration the growing proportion of syndicate-placed bonds ${ }^{3}$ and build a new measure that more accurately reflects whether a bond is reputably placed in a syndicate-placed issue.

The empirical analysis comprises two main stages. In the first stage, we use multivariate logit models to compare the likelihood of non-financial companies and banks matching with a reputable underwriter. In the second stage, we analyze and quantify the determinants of the matching using logit regressions, and compute their marginal effects.

By way of preview, we find that the odds of issuing a bond placed by a reputable underwriter were about 1.5 times greater for non-financial companies than for banks in Europe during the years 2003-2013. Banks and non-financial companies did not have a different likelihood of accessing a reputable underwriter in the pre-crisis years. However, a lower likelihood of matching a reputable underwriter was observed for banks during the subprime period and particularly, the banking crisis period. In this period, the odds of matching with a reputable underwriter were 10.92 times lower for banks.

Regarding bond and issuers' characteristics, we find that bond size was statistically and economically a more relevant factor for non-financial companies while issuer size was relatively more relevant for banks. The marginal effect of the bond size on the probability of accessing a reputable underwriter was 1.70 larger for non-financial firms than for banks. However, the relative weight of issuer size in terms of the marginal effect of bond size is larger for banks than for non-financial firms. Furthermore, the effect of bond size on the matching probability is greater for large non-financial companies than for large banks, while the effect of maturity on the matching probability is greater for banks than for non-financial companies, this difference increasing as maturity does.

The remainder of the paper is organized as follows. Section 2 reviews the extant literature. Section 3 develops a theory discussion on banks in debt markets. Section 4

\footnotetext{
${ }^{3}$ Before the year 2000, the average number of underwriters placing a bond in Europe was close to 1 . Since the beginning of the century this mean has been increasing, which is also confirmed considering the median. Since 2008 the average has surpassed 3 underwriters per deal for industrial corporate bonds.
} 
describes the dataset. The methodology is explained in Section 5. Section 6 discusses the main empirical results. Section 7 concludes.

\section{RELATED LITERATURE}

One strand of the finance literature has linked the functions performed by financial intermediaries in capital markets to its reputation. Traditionally, researchers have highlighted the certification role performed by underwriters in equity and debts issues, backing the socalled "certification hypothesis". This hypothesis argues that underwriters have the skill of reducing information asymmetries through their own reputation. Booth and Smith (1986) show that opportunist behavior can potentially arise by insiders holding extra information about the issue and that underwriter reputation is a mechanism for preventing this behavior. Beatty and Ritter (1986) argue that the certification role is enforced when reputation is at stake because banks do not have incentives to cheat. According to this role, when underwriters price issues in the capital markets they do so certifying issuers. Underwriters have incentives to maintain their reputational capital as bad future performance can damage their reputation, negatively affecting their business volume. Lead underwriters are concerned to maintain their reputation, and reputation acts as a signal for the market (Carter and Manaster, 1990). The reputational capital of these banks explains why they certify the intrinsic value of the issue. In this sense, Chemmanur and Fulghieri (1994) point out that reputable underwriters reduce the information asymmetries present in financial markets more effectively because they implement standards to evaluate issuers in order to reduce the likelihood of poor performances in the future.

These theoretical predictions have been confirmed to some extent in empirical studies examining equity IPOs and corporate bond issuance. Dong et al. (2011) use a sample of 7,407 IPOs from 1980 to 2006 to show that deals placed by reputable underwriters predict a better long-run performance. Besides, IPOs with higher underwriter reputation are shown to 
outperform IPOs with less reputable underwriters. Using a sample of 2,449 industrial bonds, Livingston and Miller (2000) conclude that reputation certifies the value of a bond issue to investors.

In the most specific study on debt issues, Fang (2005) provides empirical evidence on certification. Reputable underwriters are found to obtain higher prices (lower yields) for their issuers.

More recently, some studies have suggested a shift from the certification role to a "market power hypothesis". Chemmanur and Krishnan (2012) maintain that, as highly reputable underwriters with larger market shares are capable of attracting large institutional investors, they have the incentive to maximize the issue valuation instead of certifying its intrinsic value. In particular, they show that IPOs placed by more reputable underwriters are priced higher than their intrinsic values. Andres et al., (2014) provide evidence of higher downgrade and default risk in high-yield bonds placed by reputable underwriters.

The extant studies that have used a matching model to study the issuer-underwriter relationship have chiefly contemplated the underwriter's reputation - as well as the existence of previous and concurrent credit relationships - as driving forces of choice. In this context, the general conclusion is that previous credit relationships positively affect the probability of being chosen as underwriter in future issues because the establishment of a relationship allows the underwriter bank to generate a valuable asset that is referred to as "relationship specific capital" (Bharath et al., 2007; Drucker and Puri, 2005; Duarte-Silva, 2010; G. Kanatas and Qi, 1998; Ljungqvist et al., 2006).

Traditionally, the models used have been solely based on the choice made by one of the counterparts (Drucker and Puri, 2005; Hoberg, 2007; Ljungqvist et al., 2006; Yasuda, 2005, 2007). In these models, the issuer chooses from among a range of underwriters that are willing to place the issue. However, Fernando et al. (2005) consider matching a mutual choice. In their model, the underwriter screens the issuer's quality and at the same the issuer 
tries to identify the ability of the underwriter to place the issue. As a result of the mutual screening there is a positive assortative selection in which high-quality issuers match with reputable underwriters induced by reputation. Furthermore, the probability of the continuity of this selection decreases as the difference between issuer quality and underwriter reputation increases.

This positive assortative selection leads us to consider not just a simple issuerunderwriter matching but a reputable matching. Generally, this strand of literature has provided empirical evidence on the (deal-level and issuer-level) determinants of the reputable matching, highlighting that deal size and issuer size are particularly relevant (Andres et al., 2014; Cao et al., 2014; Dong et al., 2011; Fang, 2005; Fernando et al. 2005; Lee and Masulis, 2011; Loureiro, 2010; Neupane and Thapa, 2013). To the best of our knowledge, there is no empirical evidence about these determinants for banking corporate bonds.

Consistent with the role of reputation in the matching models, a number of studies have tried to explain what triggers the changing of underwriters for subsequent offerings as switching models. Krigman et al. (2001) study the reasons that lead issuers to switch to a new underwriter in successive equity issues, concluding that issuers do not change because they are displeased with a past issue's features. Rather, they seek reputable underwriters able to offer them a better quality service ("graduation hypothesis"). Fernando et al. (2005) show that firms will be more likely to switch underwriter as the difference between the new issuer's reputation and the reputation of the previous underwriter increases, confirming the positive assortative matching ("transaction-based hypothesis"). McKenzie and Takaoka (2013) find that the issuer and the most recent lead underwriter's reputation - along with issuers' current relationships - affect the switching choice in the Japanese bond market.

Another set of studies has further examined the ex-post value that arises from engaging with a reputable bank in an attempt to explain why issuers prefer highly reputable underwriters. This preference is likely to be explained by the better long-run performance of 
those issuers that raise capital though prestigious underwriters (Carter et al., 1998; Dong et al., 2011). Furthermore, Neupane and Thapa (2013) show that prestigious underwriters hold strong relations with institutional investors while less prestigious underwriters mainly deal with non-institutional investors. Burch et al., (2005) conclude that there is created value for those companies matched with reputable underwriters, although it depends on the type of issuance, while Fernando et al., (2012) highlight that the created value for firms is higher if the underwriter helps them to go public compared to issuing debt securities.

\section{WHAT MAKES BANKS SPECIAL?}

\subsection{Banks in an external certification market}

Baron \& Holmstrom (1980) suggest that the main reason for using a third-party underwriter is the existence of an implicit demand for certification among investors. Unlike non-financial firms, banks have the option to self-underwrite but this does not naturally provide them with the necessary certification. Issuers - banks and non-financial firms - could reduce information asymmetries by disclosing information that signals their quality. However, signaling does not entail certification. If information opaqueness increases, external certification is mainly obtained through a third-party underwriter (Hirtle, 2006).

A number of earlier studies seem to assume that banks are not in need of certification because they have better access to capital and debt markets than non-financial firms. However, this is not consistent with the larger frequency of third-party placements compared to selfunderwriting in recent years ${ }^{4}$. Figure I describes underwriting as a market for external certification.

\subsection{Banks in debt markets}

Seminal theoretical contributions on financial intermediation depict a situation in which banks, as financial intermediaries operating in financial markets, are better informed

\footnotetext{
${ }^{4}$ According to Dealogic just $25 \%$ of the banks bonds proceeds were self-issued during 2003-2013, while $75 \%$ were underwritten by third parties.
} 
than non-banks (Allen and Faulhaber, 1988; Baron, 1982; Grinblatt and Hwang, 1989; Rock, 1986; Welch, 1989). According to Fama (1985) this competitive advantage is due to their ability to process and handle information. Furthermore, the theory on certification highlights banks' role in certifying issuers' quality in the presence of information asymmetries (Booth and Smith, 1986; Chemmanur and Fulghieri, 1994). Unlike non-financial firms, banks are specialized financial intermediaries since they produce information as market participants. Furthermore, even assuming a certifying ability of non-financial firms, only financial institutions are legally allowed to provide underwriting services in capital markets. Hence, unlike non-financial firms, the double role that banks can play in the markets as both issuers (clients of underwriting services) and underwriters (suppliers of underwriting services) coupled with they better knowledge of the market and its rules should be considered. These differences extend to other related markets. For example, Sufi (2007) explores the syndicate loan market and finds that issuers that have repeated access to the market face fewer information asymmetries - because lead arrangers should hold less of the loan. Similarly, Cocco et al. (2009) also find that relationships are an important determinant of banks' access to the interbank market.

As for the comparison of banks relative to non-financial firms, it has been argued that the former are more opaque than the latter (Morgan, 2002). Flannery et al. (2013) conclude that banks are not qualitatively more opaque than matched non-financial firms during normal periods, but they are more opaque only during crises.

\subsection{Why banks may match differently with reputable underwriters?}

Theoretical models explain the value of external certification based on informational asymmetries between firms and investors (Baron, 1982; Baron \& Holmstrom, 1980; Rock, 1986). Similarly, the issuer-underwriting matching is affected by asymmetries between issuers and underwriters when the former are in need of certification (Cao et al., 2014; Fang, 2005; Fernando, Gatchev, \& Spindt, 2005; Yasuda, 2005). The role of reputation in the 
certification market is twofold. On one hand, reputable underwriters are believed to reduce these information asymmetries more efficiently as credible certifiers (Beatty and Ritter, 1986; Booth and Smith, 1986; Carter and Manaster, 1990; Chemmanur and Fulghieri, 1994). On the other hand, reputable banks put their reputation as certifiers at stake when they underwrite an issue. The reputational concern of high reputable underwriters will hinder the matching with other banks facing greater asymmetries, which are comparatively less transparent and more opaque issuers.

Therefore, a differentiated matching - a lower likelihood of obtaining a high-quality external certification - would be consistent with banks or non-financial firms facing comparatively greater informational asymmetries. The matching problem is even more acute in the case of banks as they are likely to compete in both the intermediation and the underwriting/issuing business. Specifically, as opaqueness increases, there are fewer incentives to share reputational problems with rivals.

According to earlier studies, banks, compared to non-financial firms, do not show larger informational asymmetries (opacity) in good times but seem to be more opaque during financial turmoil. This would trigger reputable underwriters to certify a lower proportion of underwriting mandates for banks than for non-financial firms.

Our approach is based on examining both banks and non-financial firms as bond issuers in a reputable framework, excluding banks' self-issued deals in order to focus on third-party placements. For comparability reasons, we employ fixed corporate bonds, sold in the same primary market and issued by both banks or non-financial firms.

\subsection{The determinants of the matching probability}

While prior literature explore the main determinants of the matching between issuers and underwriters for non-financial deals, bank bonds remain unexplored. Given the abovementioned differences between non-financial firms and banks, our baseline hypothesis would be that the determinants of the matching for non-financial firms could have a different 
impact compared to banks. In trying to explore that hypothesis, we follow earlier studies and make a distinction between deal-level characteristics and issuer-level characteristics. Theoretical and empirical investigations on equity and debt issues, summarized in Table V, have yielded some relevant evidence that we discuss in the following sub-sections.

\subsubsection{Bond-level determinants: Placement Complexity}

Some studies suggest that specific features of bond placement may increase or decrease the likelihood of matching a reputable underwriter. We focus on the main features of the design - volume of the proceeds raised and bond maturity - as proxies of placement complexity (Fang, 2005; Fernando et al., 2015; Lou and Vasvari, 2013; Song, 2004) . Prior studies show that more complex bonds are more likely to be placed by reputable underwriters (Andres et al., 2014; Fernando et al., 2015; Loureiro, 2010; McKenzie and Takaoka, 2013). Higher investor demand for reputable players coupled with higher capabilities in the development of these activities, lead issuers to choose more reputable underwriters when they want to place complex bonds (Chemmanur and Krishnan, 2012; Neupane and Thapa, 2013). In particular, placement complexity increases with bond size as underwriters must exert greater effort in marketing, pricing and selling. Additionally, the relationship between maturity and risk means that long-term bonds entail higher complexity on being brought to market. Hence, bonds aiming at large proceeds and with longer maturities are considered more complex to underwrite.

Although some empirical studies have considered that callability might be related to placement complexity (Fang, 2005; Livingston, and Miller, 2000) due to the reinvestment risk for bond buyers, the decision to include a call option is also related to information asymmetries (Banko and Zhou, 2010; Chen et al., 2010; Choi et al., 2013; Robbins and Schatzberg, 1986). Signaling theory highlights that including a call feature serves as a signal of issuers' quality in the presence of asymmetric information. Furthermore, Fernando et al., (2005) consider the existence of a positive qualitative matching between issuers and 
underwriters. Consequently, the relationship between callabillity and the reputable matching is not necessarily explained by complexity. Information asymmetries could bias the choice of issuing these bonds.

\subsubsection{Issuer-level determinants: First-time issuer}

Supporting the certification hypothesis, prior studies find that issuers' lack of experience is negatively related to the probability of a reputable matching (Andres, et al., 2014; Cao et al., 2014; Fang, 2005; Fernando et al., 2005; Yasuda, 2005). Reputable underwriters are less likely to place a bond of a relatively inexperienced issuer, thus putting their reputation at stake. Lack of experience issuing debt securities increases uncertainty about the bond issuer and the bond performance.

In financial markets, intermediaries are more frequent markets participants compared to non-financial firms. Unlike non-financial firms, a more intense day-to-day market participation might help banks to outweigh their lack of experience on the particular fixed bond market. In this sense, Kollo \& Sharpe, (2006) examines bond spreads for financial and non-financials and find that new financial issuers are not charged higher underwriter spreads, suggesting greater information asymmetries for new non-financial issuers. Consequently, we would expect the probability of matching a reputable underwriter to be more negatively affected by lack of experience in the case of non-financial firms. Similarly to Andres et al. (2014) and Gande et al., (1999), we employ the dummy variable "first-time issuer" that takes the value 1 if the issuer had not issued any corporate bond over the last 15 years (from 1988) before the sample begins in order to explore this hypothesis.

Along with experience, other concurrent performance indicators should be considered to compare the reputable matching probability of banks and non-financial firms. One might argue that banks are subject to greater regulatory scrutiny but, in fact, market discipline applies to both types of issuers. Besides, any differences in the effects of performance or solvency indicators may reveal some institutional advantage (due to regulatory or market 
differences), which is worth investigating in any case. Issuers' leverage, ROA and total assets are included to control for the level of indebtedness, profitability and issuer size (as in, for example, (Cao et al., 2014; Fang, 2005; Fernando et al., 2005; Fernando et al., 2015; Lou and Vasvari, 2013; Loureiro, 2010).

\section{DATA AND DESCRIPTIVE STATISTICS}

\subsection{Measuring Underwriter Reputation}

Some previous studies measure reputation by looking at the position that the underwriter has in the tombstone announcement that goes with an issue (Burch et al., 2005; Carter and Manaster, 1990; Kirkulak and Davis, 2005; Logue et al., 2002; Suzuki, 2010). The rationale behind this way of accounting for reputation is that underwriting banks are not placed in random positions but strategically to signal reputation. However, the difficulty that is entailed in collecting these tombstones for corporate bonds and the diminishing volume of them have played against their use as an indicator of reputation.

There are also measures based on market opinion surveys. According to Roden and Bassler (1996), market opinions do not necessarily provide better reputation measures than tombstone-based indicators.

Most of the literature has considered that market share is an accurate proxy for reputation in the underwriting business. Highly reputable underwriters should be those with greater market shares because reputation attracts more underwriting contracts. Two main measures have been built from market share information: cardinal and ordinal. A cardinal measure considers the market share as a continuous variable (Esho et al., 2006; Gande et al., 1997; Iannotta and Navone, 2008; Livingston and Miller, 2000; Megginson and Weiss, 1991; Roten and Mullineaux, 2002; Schenone, 2004) Alternatively, ordinal measures classify or rank underwriters according to their market share, considering only the top underwriters as reputable (Andres et al., 2014; Esho et al., 2006; Fang, 2005; Livingston and Miller, 2000; 
McCahery and Schwienbacher, 2010; Narayanan et al., 2006; Narayanan et al., 2004; Ross, 2010; Yasuda, 2005).

We opt for an ordinal measure. As Fang (2005) argues, this way the market structure is encompassed best because banks in capital markets are commonly seen either as heavyweight players or not. We consider as reputable those underwriters ranked in the top 7 in the annual underwriter leagues, as shown in Tables I and II using the rankings of Dealogic Debt Capital Markets 5 . The cut is not arbitrary but motivated by several reasons. The European fixed corporate bond market is less concentrated than that of the United States. The top-3 ranking is mostly used in the U.S. but in Europe there are no big differences in terms of market shares between the first-ranked banks in the underwriter league tables ${ }^{6}$. Furthermore, during the period covered, the seventh underwriter annually presented a market share of around $5 \%$, whereas the eighth fell quite below this share. In addition to this, the top 7 underwriters participated annually, as sole underwriter or in a syndicate, in more than $50 \%$ of deals ${ }^{7}$. One possible option could have been to select the main seven banks as reputable, as in Fang (2005). However, some underwriters that were reputable in the debt markets at the beginning of the sample period were not at the end.

Sole underwriter deals are easy to classify using the league tables but when a syndicate has placed the bond, there are different alternatives. Traditionally, those who have discretized the market share have considered a deal as reputably underwritten if at least one of the underwriters is at the top of the selected ranking (Andres et al., 2014; Cao et al., 2014; Fang, 2005; Fernando et al., 2005). As syndicate deals are common in Europe, the chance of considering a bond as reputably underwritten following such a criterion increases. It is highly

\footnotetext{
${ }^{5}$ Leagues have been built using as deal underwriters those considered as underwriter parents. Our rationale for considering underwriter parents is that debt financial markets are dominated by large banks. Although their subsidiaries sometimes carry out underwriting services, the esteem and reputation that influence the matching and signal quality arise from the parent bank that backs the subsidiary. As per Kollo (2005), taking underwriter parents reflects the multinational nature of the market. However, for purposes of robustness we have also built reputation measures using league tables by underwriter subsidiaries.

${ }^{6}$ The similar market share covered by the top 3 underwriters reported in Andres et al. (2014) for high-yield corporate bonds in the United States and for the top 7 in the European market $-39.3 \%$ for the top 3 in the United States and $43.17 \%$ for the top 7 in Europe - suggests that extending the reputation some places is a need not a whim.

7 This group is basically formed by Deutsche Bank, RBS, JPMorgan, Citi, BNP Paribas, HSBC and Barclays. Only three banks other than the ones cited - SG Corporate \& Investment Banking, Credit Suisse and Bank of America Merrill Lynch have entered this group in recent years.
} 
likely that bonds with more underwriters will be considered reputable if just one of those underwriters is reputable. A much stricter option is to consider a deal as reputable only if all underwriters in the syndicate belong to the top 7. However, using this criterion a syndicated deal can be considered as not reputable just because one underwriter is not in the top 7 even if the rest of them are. We opt for a more balanced option. We compute the market share that the syndicate would have had if all the banks participating in it had merged. We refer to this indicator as the "Syndicate Market Share" (SMK). A deal is considered as reputable if the average SMK is higher than the market share held by the seventh underwriter in the annual league tables. This also solves to some extent the problem of how the underwriter league tables are built, splitting all the proceeds equally among all the underwriters when there are more than one ${ }^{8}$. The calculation of the SMK is as follows:

$$
\begin{aligned}
& \text { Syndicate Market Share }(S M K)=\frac{\sum_{i=1}^{n} \text { Proceeeds underwritten } B K_{i j}}{\text { Total Proceeds issued in year } j} \times 100 \\
& n=\text { number of underwriters in a deal } \\
& \quad j=2003, \ldots, 2013
\end{aligned}
$$

Nevertheless, we have built other variables as robustness checks to ensure that the main results do not hinge upon comparing the top annual seven underwriters with the rest. These robustness checks are based on choosing underwriter subsidiaries instead of underwriter parents.

Finally, a distinctive feature of the banking corporate bonds that must be taken into account is the fact that banks can underwrite their own issues. The treatment of the so-called self-funded deals is relevant in order to compute the banks' market shares as underwriters. In this sense, the reasoning behind using the market share as proxy measure of reputation justifies the decision to exclude self-funded deals in the underwriters' market share computation. The market share of a specific underwriter will empirically capture its reputation only if this market share reflects the real volume of business performed for third parties. In

\footnotetext{
${ }^{8}$ This construction of the underwriter league tables is also done in Abrahamson et al., (2011); Aggarwal et al., (2002); Migliorati and Vismara (2014) for IPOs rankings.
} 
this sense, underwriter league tables and regression analyses for banking corporate bonds are built and estimated excluding self-funded deals.

\subsection{Database construction and variables}

Data on original fixed non-perpetual corporate bonds issued in European countries are collected from the Dealogic Debt Capital Markets database. This database includes details of the bond issue, including yield, maturity, offer price, coupon, deal underwriter, rating, etc. The sample period goes from January 1, 2003 to January 1, 2014, thereby covering the precrisis and crisis years. Our database comprises two kinds of corporate bonds: industrial bonds - whose issuers are companies different from utilities and regulated firms (SIC: 4000s) and financial firms (SIC: 6000s) - and banking bonds. We exclude deals with missing values for at least one tranche in the underwriter parent and issue rating at launch.

In order to control for issuer characteristics we matched the Dealogic dataset with the information provided about the issuer by Compustat Global ${ }^{9}$ (for industrial firms) and Bankscope-Bureau Van Dijk (for banks) ${ }^{10}$. Therefore, our sample is a matched database that includes deal characteristics (provided by Dealogic) and issuer characteristics (provided by Compustat Global and Bankscope). The sample includes 3,687 corporate bonds $(1,490$ industrial and 2,197 banking bonds) issued by 716 companies in 22 European countries ${ }^{11}$ representing a total of $\$ 2,924,462$ million. The yearly distribution of the deals is shown in Figure II.

Dealogic provides information at a tranche level and a deal level for multiple tranche bonds. We follow a deal-level approach. The main reason is that the mandate contract agreed by issuer and underwriter is mainly done at deal level. Underwriters agree on providing their services even if there is more than one tranche. When underwriter/s and issuer discuss

\footnotetext{
${ }^{9}$ Compustat Global provides financial information for publicly traded companies covering around $90 \%$ of world market capitalization. As most corporate bonds are issued by public companies, using this dataset does not reduce the potential of our research.

${ }^{10}$ Furthermore, if we had used Compustat we would not have considered all those deals carried out by savings banks and cooperative banks - which constitute a significant part of the financial systems of Spain ("cajas de ahorros"), Italy ("casse di risparmio") and Germany ("sparkassen").

${ }^{11}$ Austria, Belgium, Bulgaria, Cyprus, Czech Republic, Denmark, Finland, France, Germany, Greece, Hungary, Ireland, Italy, Luxembourg, Latvia, Lithuania, Netherlands, Poland, Portugal, Slovenia, Spain, Sweden, United Kingdom.
} 
together the issuance characteristics they also discuss tranching as a credit enhancement technique. Provided that the negotiation is done at the same moment and is included in a mandate contract, underwriters do not differ between tranches. While the proceeds, maturity and yield can vary within a deal, there is a single contract and underwriters are chosen collectively, not independently. Additionally, a deal-level approach means dealing with multiple tranches that have to be computed on a deal basis ${ }^{12}$.

We have classified the variables into three different categories: issue characteristics, issuer characteristics and underwriter characteristics. Summary statistics are offered for the whole sample distinguishing between non-financial and bank corporate bonds. With regard to the main deal characteristics, the average issue volume in our full sample is $\$ 764.36$ million with a mean maturity of 6.35 years. Non-financial corporate bond deals are brought to market by an average number of 3.20 underwriters per bond, which is in line with the 3.14 figure shown in Andres et al. (2014) for high-yield industrial bonds. However, in banking deals this average number is lower (2.19 underwriters/deal) suggesting that non-financial companies are more inclined to underwrite contracts with a syndicate of underwriters. Lastly, the large number of different underwriters merits special attention ${ }^{13}$.

This unique sample, which contains detailed information about the bond terms and issuers - industrial firms and banks - and accounts for measuring reputation in syndicatedplaced deals, represents largely the European debt markets. Therefore, it constitutes an appropriate empirical laboratory to draw conclusions about the access of industrial firms and banks to the debt markets via a reputable underwriter.

\section{METHODOLOGY}

\footnotetext{
${ }^{12}$ In those cases in which there are more than one tranche we compute weighted averages for our variables at the deal level, weighting each tranche by its tranche value proceeds. In our sample $88 \%$ of the deals are one-tranche deals. For robustness purposes we have re-run our model excluding tranched issuances, obtaining similar results, which are available upon request. ${ }_{13}$ More than 80 underwriters provide their services in all different kinds of issue. This fact reflects the high number of participants in the underwriting market although it has been said that not all of them play the same role. While so many of them do not attain at least $1 \%$ of market share, the great investment and commercial banks are those that underwrite both the most deals and the most voluminous deals.
} 


\subsection{Benchmark model on the matching probability for non-financial and bank}

\section{bonds}

Do banks and industrial companies have equal access to reputable underwriters in debt markets? The empirical strategy for addressing this question consists in estimating a binary choice model capable of explaining the probability of matching a reputable underwriter. Following previous studies, the estimation of the matching equation depends on variables that reflect issuer and bond characteristics. We use a logit model to test differences in issuerreputable underwriter matching probability, accounting for deal and issuer features. The logit model employed is expressed as follows ${ }^{14}$ :

$$
\begin{gathered}
\mathrm{E}(\mathrm{Y} \mid \mathrm{X}=\mathrm{x})=\left(\operatorname{Pr}(\text { Reputable } U W=1 \mid \mathrm{X})=\Lambda\left(\beta_{0}+\beta_{1} X_{\text {bond features }}\right.\right. \\
\left.+\beta_{2} X_{\text {issuer features }}+\beta_{3} I_{\text {ISSUER'S TYPE }}+\sum_{h=1}^{h} \text { Year }_{h}+\sum_{k=1}^{k} \text { Deal nationality }{ }_{k}+e_{i}\right)
\end{gathered}
$$

in which $X_{\text {bond features }}$ is a vector of variables reflecting the deal's features and $X_{\text {issuer features }}$ is a vector of variables containing the characteristics of the issuer firm. We include year dummies in all regressions to control for the chance of variations in debt financing over time. We also control for the nationality of the deal including country dummies in our regressions. Our main variable is a dummy controlling for the kind of issuer, being 1 if the issuer is a non-financial company. Bond features are especially important in terms of assessing the bond risk and thus how it affects its placement in the primary market. The natural logarithm of the deal proceeds is used as proxy of the bond size. The complexity of the marketing, pricing and selling activities increases with bond size. As for the maturity, the relationship between maturity and risk results in long-term bonds entailing greater complexity when they are brought into market. Therefore it can be expected that these long-

\footnotetext{
${ }^{14}$ The link function of the logit model is an S-shaped or sigmoid function whose domain is between 0 and 1 (essential for a binary choice model). This model is estimated using the Maximum Likelihood Method.
} 
term bonds are likely to be underwritten by reputable underwriters. A dummy for callable bonds is also considered. Issuers will be highly likely to call a bond if the market interest rates have declined, allowing them to create a new issue at a lower rate. In this context, investors would have to reinvest in a less favorable environment. We also include a dummy for investment grade bonds in order to control for bond quality. We account for multiple-tranche deals, adding the number of tranches forming a bond. Lastly, we control for the syndicate size. Regarding issuer characteristics, consistent with previous studies, company size is proxied by the natural logarithm of the total assets of the company at the end of the year before the issue. In order to assess how the financial structure of the company influences the matching between issuers and underwriters we have included a firm leverage measure: the debt to equity ratio. Profitability is also accounted for by the Return on Assets (ROA) ${ }^{15}$. We control for bonds issued by a special purpose company or finance vehicle ${ }^{16}$ dependent on their issuer parent. As abovementioned issuers' asymmetries matter, so we consider issuer experience in issuing corporate bonds with a dummy taking the value 1 if the issuer has not issued any corporate bond since 1988.

In order to test how banks were affected in terms of the reputable matching during the crisis, we have split the sample period initially into two sub-sample periods: pre-crisis and crisis. Given the particular features of the European case, we have further divided the crisis period into three sub-periods following the time division employed in Prokopczuk et al., (2013): subprime crisis, banking crisis and sovereign debt crisis. ${ }^{17}$

\subsection{Determinants of the matching and their impact on the probability}

After testing differences in access to a reputable underwriter depending on the financial or non-financial nature of the issuer, we focus on which bond and issuer

\footnotetext{
${ }^{15}$ As in other studies, all the balance sheet values were collected at the end of the year before the issuance.

${ }^{16}$ A finance vehicle is a company that operates as the cash pooling and treasury vehicle in financial markets issuing capital market instruments, such as commercial paper, medium-term notes, and long-term bonds.

${ }_{17}$ The subprime crisis started in July 2007 until the Lehman Brothers collapse became a fact on September 30, 2008. This period is referred to as the subprime crisis because it is when the subprime mortgages became unpaid in the United States. The next sub-sample period took place up until the end of June 2010. This is the so-called banking crisis. Finally, from July 2010 onwards the period is named the European sovereign crisis.
} 
characteristics have a higher weight in the matching distinguishing by banks and nonfinancial issuers. The sample is split into bonds issued by non-financial companies and banks. We have also used a logit model because, in the case of a univariate discrete choice model, both probit and logit produce similar results ${ }^{18}$. Additionally, the magnitude of features that have an impact on the matching cannot be done estimating a joint model with all the variables and their interactions because the interpretation of these coefficients and computing the marginal effects entails a higher degree of complexity in non-linear models, as the literature has recognized (Ai and Norton, 2003; Berry et al., 2010; Brambor et al., 2006) ${ }^{19}$. This complexity cannot be solved choosing a logit model (Norton et al., 2004). We test whether the magnitude of the coefficients differs across groups (non-banks and banks) rather than across models. Therefore, we have separately estimated and computed two marginal effects for nonfinancial and banking corporate bonds: marginal effects at means (MEM) and average marginal effects (AME).

\section{RESULTS}

\subsection{Banks and industrial companies' access to a reputable underwriter}

Table VI offers some descriptive statistics comparing non-financial companies and bank bonds and then all of them together. T-statistics are included to test the difference in means. The Wilcoxon rank sum statistic is used to test the difference in medians. Overall, these tests reveal that bonds placed by reputable underwriters are significantly different from those placed by less reputable underwriters in several aspects. The results provided in this table are consistent with the prior literature on capital and debt issues.

According to mean- and median-difference tests, more reputable underwriters appear to place bonds with larger proceeds and longer maturity. A call option, which might increase

\footnotetext{
${ }^{18}$ Nonetheless, we have tested in unreported regressions that our results are robust after using the probit function as link function.

${ }^{19}$ Prior literature has highlighted that interaction terms in non-linear models are confusing to and misinterpreted by applied researchers. In this sense, a t-test cannot infer the statistical significance of the coefficient of the interaction effect.
} 
the complexity of placing the bond, does not appear to be differently used in bonds placed by reputable or less reputable underwriters. Additionally, more reputable underwriters in our sample charge lower fees than the less reputable in industrial bonds, consistent with the differences found in Fang $(2005)^{20}$ for industrial bonds. Deals placed by reputable underwriters offer higher yields, which is in line with issuing bonds with longer maturity. Issuer size - in terms both of market capitalization and of total assets - appears to be larger for deals placed by more reputable underwriters in the case of bank bonds.

The odds ratios of the logit regressions are reported in Table VII. Models 1 and 2 refer to non-financial and bank bonds whereas Models 3 to 5 are the baseline models for the whole sample. The findings suggest that large proceeds and longer maturity bonds are more likely to be issued by reputable underwriters. Furthermore, after controlling for other issuer characteristics such as profitability, leverage and experience in the markets, firm size is positive and statistically significant for both industrial and bank issues. The results suggest that compared to banks, non-financial companies have a higher likelihood of matching a reputable underwriter. The odds of issuing a bond placed by a reputable underwriter are about 1.50 times greater for non-financial companies than for banks after controlling for bond and issuer characteristics.

\subsection{Access to a reputable underwriter: Pre-crisis vs. crisis period}

Table VIII shows univariate statistics for pre-crisis and crisis periods, including mean and median tests for differences between reputable and non-reputable underwriters. Bonds were greater in size during the crisis. There was also an increase in the syndicate size, suggesting that underwriters were reluctant to bear alone all the risks of placing an issue in a climate of high uncertainty and information asymmetries. The effect of the economic

\footnotetext{
${ }^{20}$ Unlike Andres et al. (2014), who report that issues underwritten by reputable underwriters are not integrated by a large number of underwriters. These conflicting results are due to differences in the reputation measure used. As their criterion is based on finding at least one reputable underwriter within a deal, it is logical that syndicates formed by more underwriters are more likely to include at least one reputable underwriter. We have also obtained the same result as them in unreported statistics using their criterion. Building the average market share of all the underwriters in a deal and ranking it in the league tables allows us to mend this fact that overestimates reputation in a deal and explains why different results appear in practice.
} 
deterioration is also observable in bond ratings, which on average were downgraded one point (18.75 "A+" vs. 17.49 "A"). Compared to the pre-crisis period, bonds placed by reputable underwriters during the crisis corresponded to larger, less leveraged and more profitable firms. This suggests that during the crisis, access to a reputable underwriter was more stringent for smaller firms.

Table VII shows the estimation results for the logit models before and during the crisis. There is no empirical evidence of differences in the probability of matching with a reputable underwriter between banks and non-financial companies in the pre-crisis period. However, during the financial crisis there is empirical evidence that banks faced more difficulties in the matching process compared to non-financial companies. Each column of Table IX, corresponding to a separate regression, reports the odds ratios for the sub-sample periods. During the subprime crisis and banking crisis periods their access to reputable underwriters was particularly affected. The odds of matching with a reputable underwriter were about 10.92 times lower for banks than for non-financial companies during the banking crisis. These results reflect that in this period banks were more vulnerable in terms of accessing external certification through reputable underwriters compared to non-financial companies.

\subsection{The determinants of the matching probability}

We investigate the determinant differences in the effects of deal and issuer features on the matching with reputable versus less reputable underwriters using logit multivariate regressions for non-financial issuers and banks.

Table X reports the logit estimation results for non-financial issuers. Different models are presented depending on the set of controls used: years, deal nationality and industry dummies $^{21}$. As expected, the probability of matching with a reputable underwriter increases with bond size. This finding is quite robust across all specifications. Bonds with longer

\footnotetext{
${ }^{21}$ Similar results are obtained in unreported regressions for subperiod dummies instead of year dummies.
} 
maturities are found more likely to be placed by reputable underwriters. The effect of callable bonds is not clear because it has a positive effect only at a $10 \%$ level of statistical significance before controlling for the nationality of the deal ${ }^{22}$. Furthermore, we find that first-time issuers are negatively related with the probability of matching a reputable underwriter, which suggests that newcomers face difficulties in allocating their deals. The evidence also suggests that more reputable underwriters place deals of bigger firms after controlling for issuers' industry and deal nationality. Leveraged firms, in terms of debt to equity ratio, are less likely to match with a reputable underwriter. Finally, bonds issued by finance vehicles, linked to their parent, are less likely to be placed by a reputable underwriter.

The same bond and issuer factors are also analyzed for banking companies in Table X. Large proceeds and longer maturity bonds are also more likely to be placed by reputable underwriters in the case of bank issuers. Therefore, these results are in line with the argument that reputable underwriters place complex bonds no matter the kind of issuer. The negative and significant coefficient for callable bonds suggests these bonds are less likely to be placed by a reputable underwriter in the case of bank issues. Some additional results are worth mentioning. In contrast with the findings on industrial firms, a bank being a first-time issuer does not affect the likelihood of engaging in a reputable relationship. These results would be in line with non-financial firms being more negatively affected by informational asymmetries. Finally, we find that banking corporate bonds issued by finance vehicles are more likely to be placed by a reputable underwriter but only at 10\%; this result suggests that assigning the function of issuing capital market instruments to a specialized finance vehicle may favor the reputable matching in the case of banks.

\subsection{Economic significance}

Overall, comparing the determinants of Tables $\mathrm{X}$ we find that bond size, maturity and firm size are common determinants of the reputable matching for non-financial companies

\footnotetext{
${ }^{22}$ Anyway, as Fang, (2005) argues, the increasing complexity of placing bonds with a call option supports the fact that they are more likely to be underwritten by reputable underwriters.
} 
and banks but differences appear on callable and first-issuer bonds. The non-statistically significant coefficient for industrial callable bonds after controlling for time, deal nationality and industries suggest that the relationship between callabillity and the reputable matching might not necessarily be driven by complexity. However, the negative and significant coefficient for banking bonds shows that reputable underwriters are less likely to place callable bonds. Additionally, the negative and significant coefficient of first-time issuers for industrial firms compared with the non-statistically significant of this variable for banking bonds suggest that the lack of experience issuing debt securities puts more placement difficulties on non-financial firms. In this sense, the coverage and repeated participation of banks in capital markets may outweigh the uncertainty of a first issuance for them.

We quantify the economic significance of these matching determinants by computing marginal effects at means (MEM) and average marginal effects (AME). Table XI reports the marginal effects as well as the statistical differences between industrial and bank issues. In this table, marginal effects are computed for the more robust specifications after controlling for time, deal nationality and industries.

We find that a $1 \%$ increase in the bond size from its mean value increases matching probability by 13.6 percentage points for non-financial issues and $8 \%$ for bank issues. These results suggest that bond size has a relatively higher weight in the matching for non-financial firms compared to banks, as the marginal effect of the bond size on the probability of accessing a reputable underwriter is 1.70 larger for non-financial firms than for banks. As Figure III shows, this difference is non-monotonic. At the low $5^{\text {th }}$ size percentile the $1 \%$ increase marginal effect is the same for banks and non-financial issues (around 3.67 percentage points). However, as bond size increases, the marginal effects for non-financial companies augment rapidly while for banks the increment is marginal.

With regard to issuer size, a $1 \%$ increase in the total assets from its mean value increases the probability of matching by 5.95 percentage points for non-financial companies 
and 4.75 points for banks. Figure III summarizes these results. Comparing the marginal effects of bond and issuer size for non-financial firms and banks, we find that at their median values the bond size effect is 2.17 times larger than the issuer size effect for non-financial firms while this ratio is just 1.64 times larger for banks. Therefore, the weight of the issuer size effect in terms of the marginal effect of bond size is larger for banks than for nonfinancial firms. Finally, we find that on average a $1 \%$ increase in the maturity increases the probability by 7.22 percentage points for non-financial bonds and 8.85 points for banking bonds. Therefore, the marginal effect of the maturity on the probability is 1.15 times larger for banks than for non-financial firms at means. The effect of maturity on the matching probability is greater for large banks than for large non-financial companies. These results suggest that firms' ability to adapt their bond design agreeing on longer maturities is significantly more important for banks than for non-financial companies.

\subsection{Robustness}

To check the robustness of our results we rerun the empirical tests to consider a range of factors that could potentially affect the findings. Our primary concern is to ensure that our results have not been driven by the possibility that some industrial companies and banks decided to issue corporate bonds because they had financial urgencies during crisis years, when access to interbank and equity markets was largely restricted. We have re-estimated our baseline model on the subsample of bonds of firms that issued at least once in both periods: pre-crisis and crisis period. Table XII reports the estimation results for these regressions. The findings are similar to those of Tables VII and IX. We find that, compared to non-financial companies, European banks encountered more difficulties in accessing a reputable underwriter, in particular during the banking crisis years. In this sub-sample, the odds of issuing a reputably placed bond continue to be greater (1.53 points) for non-financial companies than for banks between 2003 and 2013, with the lowest likelihood arising in the matching for banks during the subprime and banking crisis. 
Another set of robustness checks refers to the measurement of reputation. One aspect that could affect the validity of our result is computing reputation on underwriter parents instead of the underwriter subsidiaries. Consistent with parent-level results, we find unreported results qualitatively and quantitatively similar.

Additionally, one difficulty that entails comparing reputation across countries is the presence of domestic issuances for which national underwriters may be more reputable than for large international issuances ${ }^{23}$. In this sense, domestic bonds, underwritten by domestic banks and in the home market, have sharply decreased. Kollo (2005) reports that, in Europe, domestic bonds were at $62 \%$ before the adoption of the euro, whereas during $1999-2005$, according to Lau and $\mathrm{Yu}(2010)$, they were at 34\%. In our sample, 370 bonds out of 3,687 are domestic bonds $(10 \% \text { of the sample })^{24}$. In order to alleviate this concern, in unreported regressions available upon request, we have re-estimated our model separating between nondomestic bonds, Eurobonds and bonds issued in core European economies. The results obtained confirm that the odds of matching with a reputable underwriter were greater for nonfinancial companies than for banks during the sample period.

As banks may perform a double role as issuers and underwriters, we test whether banks that performed both roles had a differential matching with industrial firms compared to those banks that act only as issuers. First, we estimate the matching equation for banks that annually issued debt but did not act as underwriters - pure bank issuers. Then, we consider those banks that annually performed both roles - bank issuers \& underwriters. Finally, as some banks could have performed both roles simultaneously only occasionally, we estimate the model excluding the banks with an annual underwriting market share smaller than $0.5 \%$.

\footnotetext{
${ }^{23}$ We thank an anonymous referee for pointing out this issue.

${ }^{24}$ Following Migliorati and Vismara, (2014) we have computed a national ranking of underwriters for the core European economies (Germany, United Kingdom, France, Italy and Spain) for non-financial and bank deals during our research period. These league tables show that although some underwriters change their positions depending on the specific market, there is a clear presence of "bulge bracket banks" in the European underwriting industry. Furthermore, while during our research period commercial banks entered the underwriting industry, these banks, mainly domestic banks, only had a presence in their home market but without reaching the top positions, as the league tables reveal.

${ }^{25}$ We consider this threshold, a market share larger than $0.5 \%$, because during $2003-2013$ underwriting a single mandate in a specific year does not provide an annual market share larger than $0.5 \%$.
} 
The results of these regressions are reported in Table XIII. They are consistent with our prior findings. Both sub-samples of banks - pure bank issuers and bank issuers \& underwriters are less likely to match a reputable underwriter during the crisis compared to non-financial firms.

It could occur that banks may follow a pecking order in issuing debt depending on their own reputation as underwriters ${ }^{26}$. We control for this by including a variable in the regression that controls for the reputation of banks as underwriters. In particular, we add a dummy that takes the value 1 if the issuer bank is a Top 7 underwriter along with a variable showing the market share of the bank in the market for underwriting. As shown in Table XIV, reputable banks are more likely to match a reputable underwriter, which is consistent with the positive assortative matching.

We also account for the fact that self-underwriting coupled with banks' reputation might drive the matching. Then, an interaction term between self-underwriting and banks' reputation as underwriters (Self-underwriter*bank reputation) is introduced. Table XV shows that banks' reputation continues to be statistically significant while self-underwriting does not seem to explain the matching. The interaction term is not significant. In unreported regressions, available upon request, we have considered all the bonds issued by banks during the sample period - self-underwritten and third-party underwritten - to explain the relationship between self-underwriting and bank reputation ${ }^{27}$. As expected, we find that most reputable underwriters do not self-underwrite. Reputable banks are more likely to ask for external certification during the crisis.

Supplemental robustness regressions including extra controls are conducted. In these additional regressions we aim to account for some additional deal and issuer features in order to ensure that the main results do not hinge upon omitting variables. As additional controls we

\footnotetext{
${ }^{26}$ We thank an anonymous referee for pointing out this issue.

${ }^{27} \operatorname{Pr}($ Self - Underwrite $=1 \mid X)=\beta_{0}+\beta_{1} X_{\text {bond features }}+\beta_{2} X_{\text {issuer features }}+\beta_{3}$ Bank Reputation + Year dummies + Deal nationality dummies $+e_{i}$ 
consider other bond characteristics (floated coupon, bond purpose, currencies and placement conditions), other issuer features (past issuer, public bank, self \& not-self), and underwriting industry conditions (simultaneity).

Floated coupon is a dummy variable that controls for those bonds that have a variable rate. The currency in which the bond is fully issued is also considered to control for the exchange rate risk. SEC and Rule $144 A$ variables are dummies referring to placement conditions that the bond issuance could fulfill mainly linked to registration rights. The inclusion of Rule 144A does not mean that the bond is traded in the U.S.; but it would mean that the bond offering is available to the public in the European country of registration and that it would also be a private placement to qualified American institutional buyers.

With regard to the issuer characteristics, we have controlled for their nature. Issuer experience in capital markets can also be tested by including a dummy for past issuers in the previous 15 years before the sample period started. A positive sign is expected for nonfinancial companies' bonds in contrast to the negative sign presented in our baseline regressions for newcomers to capital markets. Finally, the public bank issuer dummy is reported for banking bonds if the issuer is not a private bank. This variable is included to reflect the bank's ownership ${ }^{28}$. Additionally, we control for self-funded deals including the variable Self\&NotSelf, a dummy that takes the value 1 if the bank has in the same year issued bonds that it has placed by itself and other bonds that have been placed by third parties. This way we control for those issuers that chose to follow both alternatives in the same natural year. Lastly, some variables that are likely to reflect the market conditions of the issue date are included. In particular, Simultaneity reflects whether the European capital markets were hot at the issue date, in order to show that issuing in a "hot market" does not alter or affect the match. Additionally, we consider two alternative time windows centered on the issue date: 30 and 90 days.

\footnotetext{
${ }^{28}$ The traditional distinction between commercial and investment banks is less relevant since in Europe most of the banks perform activities that belong to both kinds of banking.
} 
Table XVI reports the odds ratios of these regressions with extra controls. The results show that our results are robust to the inclusion of these additional control variables. Banks had more stringent access to reputable underwriters during the financial crisis, especially in the banking crisis period, after considering additional control variables. The statistical significance does not change when new variables are added into the regression. Bond size, maturity, total issue, first-issuer bonds and firm size are statistically significant in the different regressions. Table XVII presents the results for industrial and banking corporate bonds. It is worthwhile mentioning that past issuer is positive and statistically significant for nonfinancial companies, as more experience in capital markets seems to affect the matching positively. Furthermore, floated coupon bonds are less likely to be placed by reputable underwriters. And finally, bonds under Rule 144A are more likely to be placed by a reputable underwriter, which is expected because these bonds face fewer information asymmetries due to the registration requirements that they have to fulfill. In regard to banking, corporate bond results do not vary. It is noticeable that the indicator variable for public banks is not significant while the dummy controlling for banks that have placed by themselves and in a syndicate during the same year is positive but not significant.

\section{CONCLUSIONS}

This paper investigates, for the first time, the issuer-reputable underwriter matching process in corporate debt issuance by both banks and industrial companies.

We employ a combined dataset of corporate bonds issued in Europe during 20032013 by banks and non-financial companies. We find that banks had a lower probability of matching with a reputable underwriter compared to non-financial companies over the sample period. The lower likelihood for banks arose during the subprime and banking crisis in which the odds of matching with a reputable underwriter were about 5.02 and 10.92 times lower for banks respectively. However, no differences are found before the crisis. 
Our results also suggest that bond size and issuer size matter in the reputable matching. Bonds with large proceeds issued by large issuers are more likely to be placed by reputable underwriters. While bond size has a greater effect on the matching probability for non-financial companies, bank size is relatively more decisive for banks. The marginal effect of the bond size on the probability of accessing a reputable underwriter is 1.70 larger for nonfinancial firms than for banks while this difference is not observed on issuer size. The relative weight of issuer size effect in terms of the bond size effect is larger for banks than for nonfinancial firms. The effect of bond size on the matching probability increases, as size does more for industrial firms than for banks. Furthermore, the effect of maturity on the matching probability was greater for large banks than for large non-financial companies, this difference increasing as maturity does.

These results have policy implications and suggest new research avenues. Further research in this area could bring a better understanding of the information asymmetries that could affect banks as clients in the underwriting business. As the final conditions obtained on debt issuance depend on underwriter reputation, larger difficulties for banks in matching with a reputable underwriter hinder the consolidation of debt markets in Europe. Policies focused on improving market transparency and progress in the articulation of a common market framework in Europe would reduce the presence of information asymmetries, thereby favoring the consolidation of these markets and resulting in benefits for all kinds of issuers in Europe.

\section{Acknowledgements}

The authors would like to express their gratitude for the comments provided on this paper by Anthony Saunders, Bernd Schlusche, Gregory F. Udell, Douglas Cumming, William L. Megginson, José A. López, John O.S Wilson, Susanne Espenlaub, Gianfranco Vento, as well as all the seminar participants in the $14^{\text {th }}$ Infiniti Conference in International Finance, the $91^{\text {st }}$ Annual WEAI Annual Conference, the 2015 Wolpertinger Conference, the 2015 Annual Meeting of ASSET and the seminar participants at the Centre for Responsible Banking - University of St. Andrews.

\section{References}

Abrahamson, M., Jenkinson, T., Jones, H. (2011). Why Don't U.S. Issuers Demand European Fees for 
IPOs? Journal of Finance, 66(6), 2055-2082.

Aggarwal, R. K., Krigman, L., Womack, K. L. (2002). Strategic IPO underpricing, information momentum, and lockup expiration selling. Journal of Financial Economics, 66, 105-137.

Ai, C., Norton, E. C. (2003). Interaction terms in logit and probit models. Economics Letters, 80, 123 129.

Allen, F., Faulhaber, G. R. (1988). Signaling by Underpricing in the IPO Market. Journal of Financial Economics, 23, $303-323$.

Allen, F., Gale, D. (1997). Financial Markets, Intermediaries, and Intertemporal Smoothing. Journal of Political Economy, 105(3), 523-546.

Andres, C., Betzer, A., Limbach, P. (2014). Underwriter reputation and the quality of certification: Evidence from high-yield bonds. Journal of Banking \& Finance, 40, 97-115.

Banko, J. C., Zhou, L. (2010). Callable Bonds Revisited. Financial Management, 39(2), 613-641.

Baron, D. P., Holmström B., (1980). The Investment Banking Contract for New Issues Under Asymmetric Information: Delegation and the incentive problem. Journal of Finance, 35(5),11151138

Baron, D. P. (1982). A Model of the Demand for Investment Banking Advising and Distribution Services for New Issues. Journal of Finance, 37(4), 955-976.

Beatty, P., Ritter, J. R. (1986). Investment and the Initial Public Offerings. Journal of Financial Economics, 15, 213-232.

Benveniste, L. M., Ljungqvist, A., Wilhelm, W. J., Yu, X. (2003). Evidence of Information Spillovers in the Production of Investment Banking Services. Journal of Finance, 58(2), 577 - 608.

Berry, W. D., Demeritt, J. H. R., Esarey, J. (2010). Testing for interaction in binary logit and probit models: Is a product term essential? American Journal of Political Science, 54(1), 248-266.

Bharath, S. T., Dahiya, S., Saunders, A., Srinivasan, A. (2007). So what do I get? The bank's view of lending relationships. Journal of Financial Economics, 85(2), 368-419.

Booth, J. R., Smith, R. L. (1986). Capital raising, underwriting and the certification hypothesis. Journal of Financial Economics, 15, 261-281.

Brambor, T., Clark, W. R., Golder, M. (2006). Understanding interaction models: Improving empirical analyses. Political Analysis, 14, 63-82.

Burch, T. R., Nanda, V., Warther, V. (2005). Does it pay to be loyal? An empirical analysis of underwriting relationships and fees. Journal of Financial Economics, 77(3), 673-699.

Cao, C. X., Chen, C., Wang, J. Q. (2014). Underwriter reputation and pricing of risk: evidence from seasoned equity offerings. Review of Quantitative Finance and Accounting. 44(4), 609-643

Carter, R. B., Dark, F. H., Singh, A. K. (1998). Underwriter Reputation , Initial Returns , and the Long-Run Performance of IPO Stocks. Journal of Finance, 53(1), 285-311.

Carter, R., Manaster, S. (1990). Initial Public Offerings and Underwriter Reputation. Journal of Finance, 45(4), 1045-1067.

Chemmanur, T. J., Fulghieri, P. (1994). Investment Bank Reputation , Information Production , and Financial Intermediation. Journal of Finance, 49(1), 57-79.

Chemmanur, T. J., Krishnan, K. (2012). Heterogeneous Beliefs, IPO Valuation, and the Economic Role of the Underwriter in IPOs. Financial Management, 41(4), 769-811.

Chen, C., Shi, H., Xu, H. (2013). Underwriter Reputation, Issuer Ownership, and Pre-IPO Earnings Management: Evidence from China. Financial Management, 42(3), 647-677.

Chen, Z., Mao, C. X., Wang, Y. (2010). Why firms issue callable bonds: Hedging investment uncertainty. Journal of Corporate Finance, 16(4), 588-607.

Choi, S., Jameson, M., Jung, M. (2013). The issuance of callable bonds under information asymmetry. Journal of Empirical Finance, 21(1), 1-14.

Cocco, J. F., Gomes, F. J., Martins, N. C. (2009). Lending relationships in the interbank market. Journal of Financial Intermediation, 18(1), 24-48.

Dewatripont, M., Maskin, E. (1995). Credit and Efficiency in Centralized and Economies Decentralized Economies. The Review of Economic Studies, 62(4), 541-555.

Diamond, D. W. (1984). Financial Intermediation and Delegated Monitoring. The Review of Economic Studies, 51(3), 393-414.

Diamond, D. W. (1991). Monitoring and Reputation: The Choice between Bank Loans and Directly Placed Debt. Journal of Political Economy, 99(4), 689-721.

Dong, M., Michel, J.-S., Pandes, J. A. (2011). Underwriter Quality and Long-Run. Financial Management, 40(1), 219-251. 
Drucker, S., Puri, M. (2005). On the Benefits of Concurrent Lending. Journal of Finance, 60(6), 2763-2799.

Duarte-Silva, T. (2010). The market for certification by external parties: Evidence from underwriting and banking relationships. Journal of Financial Economics, 98(3), 568-582.

Esho, N., Kollo, M. G., Sharpe, I. G. (2006). Eurobond underwriter spreads. Accounting and Finance, 46(1), 71-95.

Fama, E. F. (1985). What's different about banks? Journal of Monetary Economics, 15, 29-39.

Fang, L. H. (2005). Investment Bank Reputation and the Price and Quality of Underwriting Services. Journal of Finance, 60(6), 2729-2761.

Fernando, C. S., Gatchev, V. A., May, A. D., Megginson, W. L. (2015). Prestige without purpose? Reputation, differentiation, and pricing in U.S. equity underwriting. Journal of Corporate Finance, 32, 41-63.

Fernando, C. S., Gatchev, V. A., Spindt, P. A. (2005). Wanna Dance? How Firms and Underwriters Choose Each Other. Journal of Finance, 60(5), 2437-2469.

Fernando, C. S., May, A. D., Megginson, W. L. (2012). The Value of Investment Banking Relationships : Evidence from the Collapse of Lehman Brothers. Journal of Finance, 68(1), 235270.

Flannery, M. J., Kwan, S. H., Nimalendran, M. (2013). The 2007-2009 financial crisis and bank opaqueness. Journal of Financial Intermediation, 22(1), 55-84.

Gande, A., Puri, M., Saunder, A., Walter, I. (1997). Banks underwriting debt securities: Modern evidence. The Review of Financial Studies, 10(4), 1175 - 1202.

Gande, A., Puri, M., Saunders, A. (1999). Bank entry , competition, and the market for corporate securities underwriting. Journal of Financial Economics, 54, 165-195.

Grinblatt, M., Hwang, C. Y. (1989). Signaling and the Pricing of New Issues. Journal of Finance, 44(2), 393-420.

Hirtle, B. (2006). Stock Market Reaction to Financial Statement Certification by Bank Holding Company CEOs. Journal of Money, Credit and Banking, 38(5), 1263-1291.

Hoberg, G. (2007). The Underwriter Persistence Phenomenon. Journal of Finance, 62(3), 1169-1206.

Iannotta, G., Navone, M. (2008). Which Factors Affect Bond Underwriting Fees? The Role of Banking Relationships. European Financial Management, 14(5), 944-961.

Kanatas, G., Qi, J. (1998). Underwriting by Commercial Banks: Incentive Conflicts , Scope Economies, and Project Quality. Journal of Money, Credit and Banking, 30(1), 119-133.

Kanatas, G., Qi, J. (2003). Integration of Lending and Underwriting: Implications of Scope Economies. Journal of Finance, 58(3), 1167-1191.

Kirkulak, B., Davis, C. (2005). Underwriter reputation and underpricing: Evidence from the Japanese IPO market. Pacific-Basin Finance Journal, 13(4), 451-470.

Kollo, M. G., Sharpe, I. G. (2006) Relationships and underwriter spreads in the Eurobond floating rate note market. The Journal of Financial Research, 29(2), 163-180.

Kollo, M. G. (2005). Underwriter Competition and Gross Spread in the Eurobond Market. European Central Bank Working Paper.

Krigman, L., Shaw, W. H., Womack, K. L. (2001). Why do firms switch underwriters ? Journal of Financial Economics, 60, 245-284.

Lau, S. T., Yu, J. (2010). Does proximity matter in international bond underwriting? Journal of Banking and Finance, 34(9), 2027-2041.

Lee, G., Masulis, R. W. (2011). Do more reputable financial institutions reduce earnings management by IPO issuers? Journal of Corporate Finance, 17(4), 982-1000.

Leland, E., Pyle, H. (1977). Information Asymmetries, Financial Structure, and Financial Intermediation. Journal of Finance, 32(2), 381-387.

Livingston, M., Miller, R. E. (2000). Investment Bank Reputation and the Underwriting of Nonconvertible Debt. Financial Management, 29(2), 21-34.

Ljungqvist, A., Marston, F., Wilhelm, W. J. (2006). Competing for Securities Underwriting Mandates: Banking Relationships and Analyst Recommendations. Journal of Finance, 61(1), 301-340.

Logue, D. E., Rogalski, R. J., Seward, J. K., Johnson, L. F. (2002). What Is Special about the Roles of Underwriter Reputation and Market Activities in Initial Public Offerings? The Journal of Business, 75(2), 213-243.

Lou, Y., Vasvari, F. P. (2013). The Role of Reputable Auditors and Underwriters in the Design of 
Bond Contracts. Journal of Accounting, Auditing and Finance, 28(1), 20-52.

Loureiro, G. (2010). The reputation of underwriters: A test of the bonding hypothesis. Journal of Corporate Finance, 16(4), 516-532.

McCahery, J., Schwienbacher, A. (2010). Bank reputation in the private debt market. Journal of Corporate Finance, 16(4), 498-515.

McKenzie, C. R., Takaoka, S. (2013). The matching of lead underwriters and issuing firms in the Japanese corporate bond market. Mathematics and Computers in Simulation, 93, 86-97.

Megginson, W. L., Weiss, K. A. (1991). Venture Capitalist Certification in Initial Public Offerings. Journal of Finance, 46(3), 879 - 903.

Migliorati, K., Vismara, S. (2014). Ranking Underwriters of European IPOs. European Financial Management, 20(5), 891-925.

Morgan, D. P. (2002). Rating Banks: Risk and Uncertainty in an Opaque Industry. The American Economic Review, 92(4), 874-888.

Narayanan, R. P., Rangan, K. P., Rangan, N. K. (2004). The role of syndicate structure in bank underwriting. Journal of Financial Economics, 72(3), 555-580.

Narayanan, R. P., Rangan, K. P., Rangan, N. K. (2006). The Effect of Private-Debt-Underwriting Reputation on Bank Public-Debt Underwriting. Review of Financial Studies, 20(3), 597-618.

Neupane, S., Thapa, C. (2013). Underwriter reputation and the underwriter-investor relationship in IPO markets. Journal of International Financial Markets, Institutions and Money, 24, 105-126.

Norton, E. C., Wang, H., Ai, C. (2004). Computing Interaction Effects and Standards Errors in Logit and Probit Models. Stata Journal, 4(2), 154-167.

Petrella, G., Resti, A. (2013). Supervisors as information producers: Do stress tests reduce bank opaqueness? Journal of Banking and Finance, 37(12), 5406-5420.

Prokopczuk, M., Siewert, J. B., Vonhoff, V. (2013). Credit risk in covered bonds. Journal of Empirical Finance, 21, 102-120.

Puri. M., (1996). Commercial banks in investment banking. Conflict of interest or certification role?. Journal of Financial Economics, 40, 373-401

Robbins, E. R., Schatzberg, J. D. (1986). Callable Bonds : A Risk-Reducing Signalling Mechanism. Journal of Finance, 41(4), 935-949.

Rock, K. (1986). Why new issues are underpriced? Journal of Financial Economics, 15(1-2), 187212.

Roden, P. F., Bassler, J. (1996). Effect of Underwriter Prestige on the Interest Cost of Municipal Bond Offerings. The Financial Review, 31(3), 641-666.

Ross, D. G. (2010). The "Dominant Bank Effect:" How High Lender Reputation Affects the Information Content and Terms of Bank Loans. Review of Financial Studies, 23(7), 2730-2756.

Roten, I. C., Mullineaux, D. J. (2002). Debt underwriting by commercial bank-affiliated firms and investment banks: More evidence. Journal of Banking \& Finance, 26(4), 689-718.

Schenone, C. (2004). The Effect of Banking Relationships on the Firm's IPO Underpricing. Journal of Finance, 59(6), 2903-2957.

Song, W.L. (2004). Competition and Coalition among Underwriters: The Decision to Join a Syndicate. Journal of Finance, 59(5), 2421-2444.

Sufi, A. (2007). Information Asymmetry and Financing Arrangements: Evidence from Syndicated Loans. Journal of Finance, 62(2), 629-668.

Suzuki, K. (2010). Do the equity holding and soundness of bank underwriters affect issue costs of SEOs? Journal of Banking \& Finance, 34(5), 984-995.

Welch, I. (1989). Seasoned Offerings, Imitation Costs, and the Underpricing of Initial Public Offerings. Journal of Finance, 44(2), 421-449.

Yasuda, A. (2005). Do Bank Relationships Affect the Firm's Underwriter Choice in the CorporateBond Underwriting Market? Journal of Finance, 60(3), 1259-1292.

Yasuda, A. (2007). Bank relationships and underwriter competition: Evidence from Japan. Journal of Financial Economics, 86(2), 369-404. 


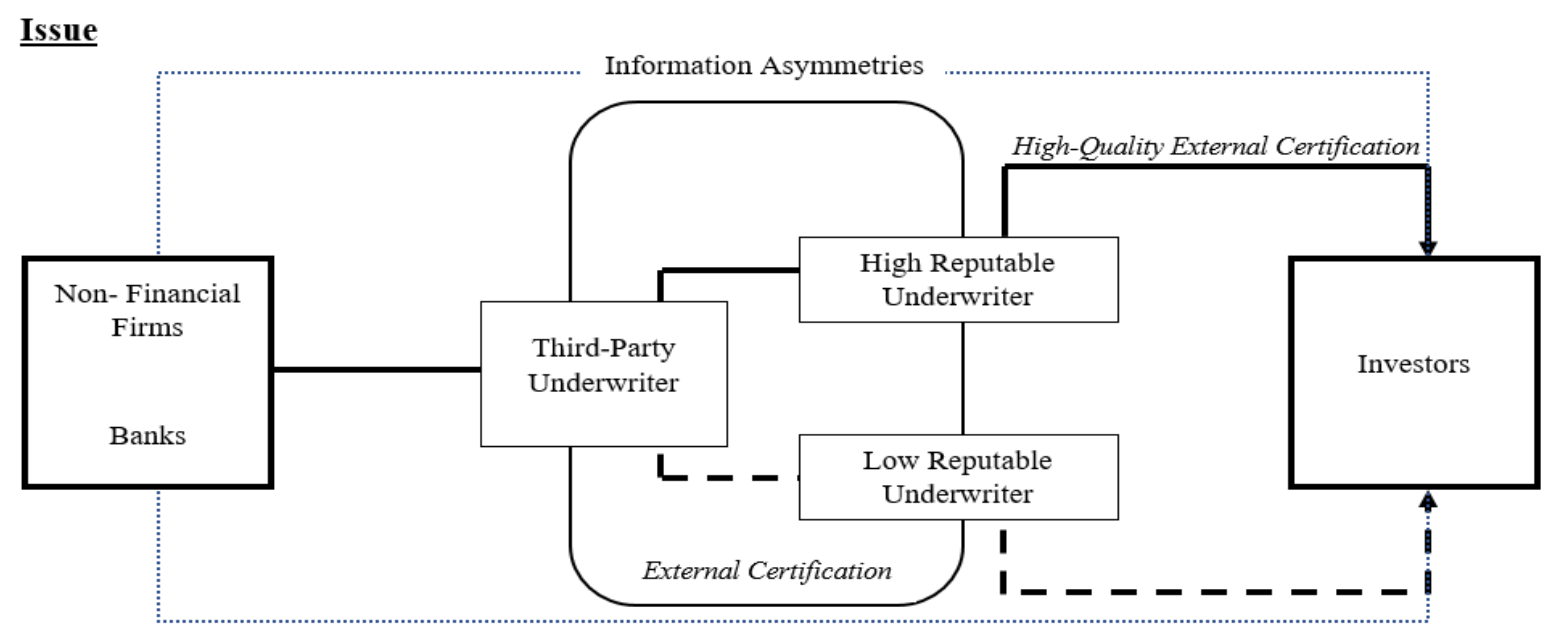

\section{Self-issue}

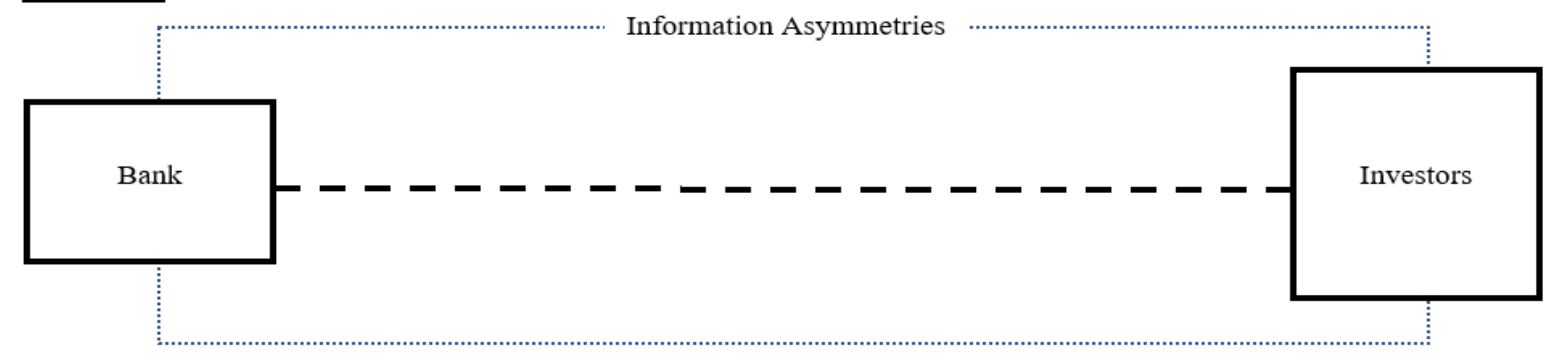

FIGURE I

UNDERWRITING: A MARKET FOR EXTERNAL CERTIFICATION 
TABLE I

ANNUAL TOP 10 UNDERWRITER PARENTS MARKET SHARE RANKINGS IN THE EUROPEAN FIXED CORPORATE BOND MARKET.

NON-FINANCIAL COMPANIES BONDS (2003-2013)

\begin{tabular}{|c|c|c|c|c|c|c|c|c|c|c|c|}
\hline Rank & 2003 & 2004 & 2005 & 2006 & 2007 & 2008 & 2009 & 2010 & 2011 & 2012 & 2013 \\
\hline 1 & Deutsche Bank & Deutsche Bank & BNP Paribas & Deutsche Bank & Deutsche Bank & RBS & Deutsche Bank & Deutsche Bank & Deutsche Bank & HSBC & Deutsche Bank \\
\hline 2 & Citi & BNP Paribas & Citi & Barclays & Citi & Deutsche Bank & RBS & Barclays & Citi & Barclays & HSBC \\
\hline 3 & JPMorgan & JP Morgan & Credit Suisse & JPMorgan & HSBC & BNP Paribas & BNP Paribas & BNP Paribas & RBS & RBS & BNP Paribas \\
\hline 4 & BNP Paribas & Citi & HSBC & Morgan Stanley & JPMorgan & HSBC & SG Corporate & RBS & BNP Paribas & Deutsche Bank & Barclays \\
\hline 5 & HSBC & Barclays & Deutsche Bank & BNP Paribas & BNP Paribas & JPMorgan & HSBC & HSBC & Barclays & BNP Paribas & JPMorgan \\
\hline 6 & RBS & Credit Suisse & SG Corporate & Citi & RBS & Barclays & Barclays & $\begin{array}{l}\text { BofA Merrill } \\
\text { Lynch }\end{array}$ & JPMorgan & JPMorgan & RBS \\
\hline 7 & Barclays & ABN AMRO & ABN AMRO & RBS & Barclays & SG Corporate & JPMorgan & Citi & SG Corporate & Citi & Citi \\
\hline 8 & Goldman Sachs & Goldman Sachs & JPMorgan & HSBC & SG Corporate & Goldman Sachs & Citi & SG Corporate & $\begin{array}{l}\text { BofA Merrill } \\
\text { Lynch }\end{array}$ & SG Corporate & $\begin{array}{l}\text { BofA Merrill } \\
\text { Lynch }\end{array}$ \\
\hline 9 & Credit Suisse & HSBC & Barclays & ABN AMRO & Morgan Stanley & Calyon & Calyon & JPMorgan & HSBC & Goldman Sachs & Goldman Sachs \\
\hline 10 & ABN AMRO & Merrill Lynch & $\mathrm{RBC}$ & Merrill Lynch & Credit Suisse & Merrill Lynch & $\begin{array}{l}\text { BofA Merrill } \\
\text { Lynch }\end{array}$ & $\begin{array}{l}\text { Credit Agricole } \\
\text { CIB }\end{array}$ & Goldman Sachs & $\begin{array}{l}\text { BofA Merrill } \\
\text { Lynch }\end{array}$ & SG Corporate \\
\hline
\end{tabular}

TABLE II

ANNUAL TOP 10 UNDERWRITER PARENTS MARKET SHARE RANKINGS IN THE EUROPEAN FIXED CORPORATE BOND MARKET.

BANKING BONDS (excluded self-funded deals) (2003-2013)

\begin{tabular}{|c|c|c|c|c|c|c|c|c|c|c|c|}
\hline \multirow[b]{2}{*}{ Rank } & \multirow{2}{*}{\multicolumn{11}{|c|}{2009}} \\
\hline & & 2004 & & & & & 2009 & 2010 & 2011 & 2012 & 2013 \\
\hline 1 & UBS & UBS & UBS & Deustche Bank & Deutsche Bank & RBS & Barclays & Barclays & HSBC & BNP Paribas & Deutsche Bank \\
\hline 2 & Credit Suisse & ING & Calyon & UBS & Barclays & BNP Paribas & HSBC & HSBC & BNP Paribas & Natixis & $\mathrm{HSBC}$ \\
\hline 3 & Barclays & RBS & Deutsche Bank & ABN AMRO & Credit Suisse & HSBC & RBS & RBS & Barclays & JPMorgan & Goldman Sachs \\
\hline 4 & RBS & Deutsche Bank & ABN AMRO & Barclays & Calyon & Barclays & BofA Merrill Lynch & BNP Paribas & Goldman Sachs & Barclays & JPMorgan \\
\hline 5 & Deutsche Bank & Credit Suisse & BNP Paribas & BNP Paribas & BNP Paribas & Deutsche Bank & UBS & Deutsche Bank & BofA Merrill Lynch & Deutsche Bank & Barclays \\
\hline 6 & ABN AMRO & JP Morgan & Credit Suisse & Calyon & JPMorgan & Calyon & BNP Paribas & BofA Merrill Lynch & Deutsche Bank & BofA Merrill Lynch & BNP Paribas \\
\hline 7 & BNP Paribas & Fortis & UniCredit & Credit Suisse & UBS & UBS & JPMorgan & JPMorgan & RBS & Goldman Sachs & BofA Merrill Lynch \\
\hline 8 & West LB & Citi & JPMorgan & UniCredit & UniCredit & SG Corporate & Deutsche Bank & Credit Suisse & JPMorgan & HSBC & Credit Agricole \\
\hline 9 & HSBC & ABN AMRO & Rabobank & Rabobank & Rabobank & Banca IMI & Credit Suisse & SG Corporate & Credit Suisse & Citi & Citi \\
\hline 10 & Morgan Stanley & Calyon & WestLB & RBS & HSBC & Morgan Stanley & SG Corporate & Citi & Citi & Credit Suisse & SG Corporate \\
\hline
\end{tabular}




\section{TABLE III}

\section{SAMPLE SUMMARY STATISTICS}

This table presents the summary statistics (mean and median) for the main variables in the sample dataset. The ttest values are based on two tails t-test for difference in means between the two groups of corporate bonds and Wilcoxom Mann-Whitney test is used for medians. *, **,*** Different is significant at less than $10 \%, 5 \%, 1 \%$ level.

\begin{tabular}{|c|c|c|c|c|c|c|}
\hline & & \multicolumn{3}{|c|}{ Corporate bonds } & \multicolumn{2}{|c|}{ Tests } \\
\hline & & All & Non-financial & Banking & $\mathrm{T}$ - test & $\begin{array}{c}\text { Wilcoxom } \\
\text { Mann - Whitney }\end{array}$ \\
\hline \multirow{2}{*}{ Proceeds (\$ mill) } & Mean & 764.36 & 782.21 & 752.79 & \multirow{2}{*}{0.98} & \multirow{2}{*}{$8.37 * * *$} \\
\hline & Median & 446.72 & 551.81 & 343.95 & & \\
\hline \multirow{2}{*}{ Maturity (years) } & Mean & 6.35 & 7.04 & 5.90 & \multirow{2}{*}{$7.96 * * *$} & \multirow{2}{*}{$14.34 * * *$} \\
\hline & Median & 5 & 6.06 & 5 & & \\
\hline \multirow{2}{*}{ Yield (\%) } & Mean & 4.56 & 4.78 & 4.41 & \multirow{2}{*}{$4.64 * * *$} & \multirow{2}{*}{$8.45 * * *$} \\
\hline & Median & 4.19 & 4.55 & 3.96 & & \\
\hline \multirow{2}{*}{ Coupon (\%) } & Mean & 4.54 & 4.75 & 4.41 & \multirow{2}{*}{$4.83 * * *$} & \multirow{2}{*}{$7.89 * * *$} \\
\hline & Median & 4.20 & 4.50 & 4 & & \\
\hline \multirow{2}{*}{ Gross Fees Spread (\%) } & Mean & 0.76 & 0.59 & 0.85 & \multirow{2}{*}{$-7.88 * * *$} & \multirow{2}{*}{$-5.79 * * *$} \\
\hline & Median & 0.45 & 0.35 & 0.66 & & \\
\hline \multirow{2}{*}{ Effective Rating at Launch } & Mean & 17.91 & 15.41 & 19.37 & \multirow{2}{*}{$-36.28 * * *$} & \multirow{2}{*}{$-33.12 * * *$} \\
\hline & Median & 19 & 15 & 20 & & \\
\hline \multirow{2}{*}{ Number of Underwriters } & Mean & 2.59 & 3.20 & 2.19 & \multirow{2}{*}{$18.61 * * *$} & \multirow{2}{*}{$19.46 * * *$} \\
\hline & Median & 2 & 3 & 2 & & \\
\hline Callable & $\%$ & $12.26 \%$ & $22.26 \%$ & $5.77 \%$ & $14.01 * * *$ & $15.19 * * *$ \\
\hline Collateralized & $\%$ & $1.15 \%$ & $2.26 \%$ & $0.43 \%$ & $4.50 * * *$ & $5.19 * * *$ \\
\hline Private Placement & $\%$ & $7.61 \%$ & $6.84 \%$ & $8.01 \%$ & -1.45 & -1.43 \\
\hline Euro Placement & $\%$ & $74.02 \%$ & $77.64 \%$ & $71.48 \%$ & $4.55 * * *$ & $4.45 * * *$ \\
\hline SEC & $\%$ & $3.26 \%$ & $5.44 \%$ & $1.83 \%$ & $5.43 * * *$ & $5.97 * * *$ \\
\hline Rule 144A & $\%$ & $7.68 \%$ & $11.96 \%$ & $4.91 \%$ & $7.42 * * *$ & $7.99 * * *$ \\
\hline Issuer / Originator & number & 716 & 437 & 279 & & \\
\hline Issuer / Originator Parents & number & 476 & 345 & 131 & & \\
\hline Underwriters & number & 146 & 90 & 146 & & \\
\hline Nationality & number & 22 & 20 & 20 & & \\
\hline Deals & $\mathrm{n}$ & 3,687 & 1,490 & 2,197 & & \\
\hline Tranches & $\mathrm{n}$ & 4,343 & 1,874 & 2,469 & & \\
\hline
\end{tabular}

TABLE IV

\section{DISTRIBUTION OF UNDERWRITERS IN THE SAMPLE}

This table presents the number and percentage of sole and multiple deals in the sample by kind of corporate bond.

\begin{tabular}{|c|c|c|c|c|}
\cline { 2 - 5 } \multicolumn{1}{c|}{} & \multicolumn{2}{c|}{ Non-financial issues } & \multicolumn{2}{c|}{ Banking issues } \\
\hline Sole underwriter & 210 & $14.09 \%$ & 907 & $41.29 \%$ \\
\hline 2 Underwriters & 422 & $28.32 \%$ & 575 & $26.17 \%$ \\
\cline { 2 - 5 } 3 Underwriters & 294 & $19.73 \%$ & 252 & $11.47 \%$ \\
\cline { 2 - 5 } 4 Underwriters & 292 & $19.60 \%$ & 286 & $13.02 \%$ \\
\cline { 2 - 5 } 5 Underwriters & 133 & $8.93 \%$ & 142 & $6.46 \%$ \\
\cline { 2 - 5 } > 5 Underwriters & 139 & $9.33 \%$ & \multicolumn{2}{c}{2,197 deals } \\
\hline Total & \multicolumn{2}{c}{1,490 deals } & \multicolumn{2}{c}{} \\
\hline \multicolumn{2}{c}{}
\end{tabular}

\section{FIGURE II}

DEALS AND PROCEEDS VOLUME ISSUED IN THE SAMPLE (2003 -20013)

These graphs plot the number of bonds and the volume of proceeds issued into the primary capital markets in the sample. The left-hand side graph is referred to the number of bonds while the right-hand side graph plots the volume of proceeds in millions of American dollars placed annually.

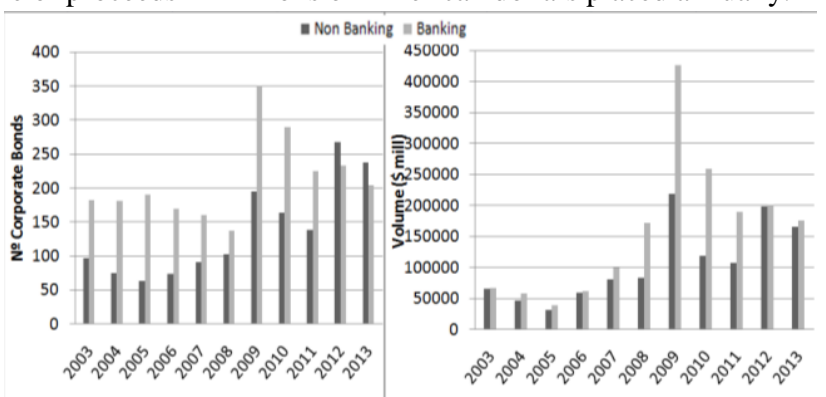


TABLE $V$

EMPIRICAL PAPERS' RESULTS IN THE ISSUER-UNDERWRITER MATCHING

This table presents the main empirical findings in the issuer-underwriter matching in the prior literature for equity and debt issues.

\begin{tabular}{|c|c|c|c|c|}
\hline Variables & Sign & Empirical Papers & Proxy used & Dummy \\
\hline Firm Size & + & $\begin{array}{l}\text { Fang (2005) } \\
\text { Fernando, Gatchev and Spindt (2005) } \\
\text { Fernando et al., (2015) } \\
\text { Loureiro (2010) } \\
\text { Cao et al., (2014) } \\
\text { Lou and Vasvari (2013) }\end{array}$ & $\begin{array}{l}\text { Market value } \\
\text { Log (Market capitalization value) } \\
\text { Log (Market capitalization value) } \\
\text { Log (Total Assets) } \\
\text { Log (Market capitalization value) } \\
\text { Log (Total Assets) \& Log (Total Assets) }\end{array}$ & \\
\hline Issue Size & + & $\begin{array}{l}\text { Fernando et al., (2005) } \\
\text { Fernando et al., (2015) } \\
\text { Andres et al., (2014) } \\
\text { Loureiro (2010) } \\
\text { Benveniste et al., (2003) } \\
\text { Chen, Shi and Xu, (2013) } \\
\end{array}$ & $\begin{array}{l}\text { Log (proceeds) } \\
\text { Log (proceeds) } \\
\text { Log (proceeds) } \\
\text { Log (proceeds) } \\
\text { Log (proceeds) } \\
\text { Log (proceeds) } \\
\end{array}$ & \\
\hline Maturity & + & Fang (2005) & Log (Years) & \\
\hline Callable & $+/$ Non-significant & \begin{tabular}{|l|} 
Fang (2005) \\
Andres et al., (2014) \\
\end{tabular} & \begin{tabular}{|l|} 
Callable \\
Redeemable
\end{tabular} & $\begin{array}{l}\text { Dummy } \\
\text { Dummy }\end{array}$ \\
\hline Firm Profitability & - / Non-significant & $\begin{array}{l}\text { Fang (2005) } \\
\text { Fernando, Gatchev and Spindt (2005) } \\
\text { Fernando et al., (2015) }\end{array}$ & \begin{tabular}{|l} 
ROA \\
Earnings / Dividend \\
ROA
\end{tabular} & Dummy \\
\hline Firm Leverage & - & \begin{tabular}{|l} 
Lou and Vasvari (2013) \\
\end{tabular} & \begin{tabular}{|l} 
Long-term debt to total assets \& Leverage ${ }^{2}$ \\
\end{tabular} & \\
\hline Deal Rating & + & $\begin{array}{l}\text { Fang (2005) } \\
\text { Fernando, Gatchev and Spindt (2005) } \\
\text { Andres et al., (2014) }\end{array}$ & $\begin{array}{l}\text { Investment Grade } \\
\text { Investment Grade } \\
\text { BB / B }\end{array}$ & $\begin{array}{l}\text { Dummy } \\
\text { Dummy } \\
\text { Dummy }\end{array}$ \\
\hline Collateralized & - / Non-significant & Andres et al., (2014) & \begin{tabular}{|l|} 
Unsecured \\
\end{tabular} & Dummy \\
\hline Volatility / Risk. & - / Non-significant & $\begin{array}{l}\text { Fang (2005) } \\
\text { Fernando, Gatchev and Spindt (2005) } \\
\text { Andres et al., (2014) } \\
\text { Cao et al.,., (2014) } \\
\text { Cao et al., (2014) } \\
\text { Benveniste et al., (2003) }\end{array}$ & $\begin{array}{l}\text { Sigma (Issuer's stock volatility) } \\
\text { Standard error of daily returns after the offer } \\
\text { Beta } \\
\text { Std. of market excess return over past year } \\
\text { Market volatility } \\
\text { Uncertainty (Expected price variation ) }\end{array}$ & \\
\hline Number of forecast & + & \begin{tabular}{|l|} 
Fernando, Gatchev and Spindt (2005) \\
\end{tabular} & $\log \left(\mathrm{n}^{\circ}\right.$ of forecast $)$ & \\
\hline Venture backed firm & + & $\begin{array}{l}\text { Fernando, Gatchev and Spindt (2005) } \\
\text { Loureiro (2010) } \\
\text { Benveniste et al., (2003) }\end{array}$ & $\begin{array}{l}\text { Venture backed company } \\
\text { Venture backed company } \\
\text { Venture backed company }\end{array}$ & $\begin{array}{l}\text { Dummy } \\
\text { Dummy } \\
\text { Dummy }\end{array}$ \\
\hline Public Firm & + & Andres et al., (2014) & \begin{tabular}{|l|} 
Public firm \\
\end{tabular} & Dummy \\
\hline Rule 144A & Non-significant & Andres et al., (2014) & \begin{tabular}{|l|} 
Rule 144A \\
\end{tabular} & Dummy \\
\hline High Yield Index & + & Andres et al., (2014) & \begin{tabular}{|l|} 
High Yield Index \\
\end{tabular} & \\
\hline Protection of Shareholders Rights & - & Loureiro (2010) & \begin{tabular}{|l|} 
Protection of shareholders rights \\
\end{tabular} & Dummy \\
\hline Book Equity to Market Relation & + & \begin{tabular}{|l|} 
Cao et al., (2014) \\
\end{tabular} & Book equity value / Mkt. capitalization & \\
\hline Auditor & + / Non-significant & $\begin{array}{l}\text { Lou and Vasvari (2013) } \\
\text { Chen, Shi and Xu, (2013) }\end{array}$ & \begin{tabular}{|l|} 
Reputable auditor \\
Auditor BIG four
\end{tabular} & $\begin{array}{l}\text { Dummy } \\
\text { Dummy }\end{array}$ \\
\hline
\end{tabular}


TABLE VI

UNIVARIATE STATISTICS BY UNDERWRITER REPUTATION

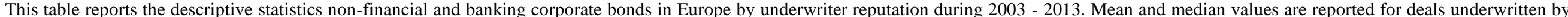

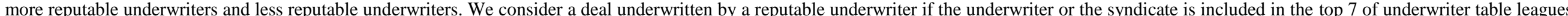

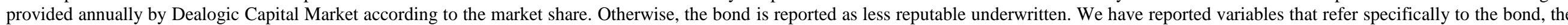

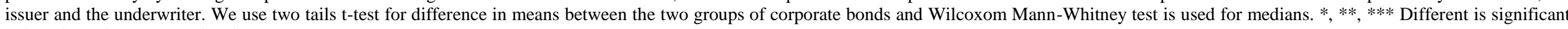
at less than $10 \%, 5 \%, 1 \%$ level.

\begin{tabular}{|c|c|c|c|c|c|c|c|c|c|c|c|c|}
\hline \multirow{3}{*}{ Bond characteristics } & \multicolumn{6}{|c|}{ NON-FINANCIAL CORPORATE BONDS } & \multicolumn{6}{|c|}{ BANK CORPORATE BONDS } \\
\hline & \multicolumn{2}{|c|}{ Reputable Underwriter } & \multicolumn{2}{|c|}{ Less Reputable Underwriter } & \multirow{2}{*}{$\begin{array}{c}\text { t-test } \\
\mathbf{t} \text {-value }\end{array}$} & \multirow{2}{*}{$\begin{array}{c}\text { z-test } \\
\text { z-value }\end{array}$} & \multicolumn{2}{|c|}{ Reputable Underwriter } & \multicolumn{2}{|c|}{ Less Reputable Underwriter } & \multirow{2}{*}{$\frac{\text { t-test }}{\mathrm{t}-\text { value }}$} & \multirow{2}{*}{$\begin{array}{c}\text { z-test } \\
\text { - value }\end{array}$} \\
\hline & Mean & Median & Mean & Median & & & Mean & Median & Mean & Median & & \\
\hline Issue Size (\$ mill) & 947.11 & 673.06 & 693.10 & 476.77 & $-5.22 * * *$ & $-7.18^{* * *}$ & 814.41 & 373.64 & 721.96 & 329.31 & $-2.02 * *$ & $-3.69 * * *$ \\
\hline Maturity (years) & 8.05 & 7.00 & 6.49 & 5.71 & $-5.75^{* * *}$ & $-6.66 * * *$ & 6.97 & 5.00 & 5.36 & 4.58 & $-8.74 * * *$ & $-10.94 * * *$ \\
\hline Yield (\%) & 5.24 & 5.00 & 4.53 & 4.28 & $-6.47 * * *$ & $-7.26 * * *$ & 4.42 & 4.18 & 4.41 & 3.85 & -0.14 & $-2.04 * *$ \\
\hline Coupon $(\%)$ & 5.16 & 5.00 & 4.53 & 4.25 & $-6.04 * * *$ & $-6.90 * * *$ & 4.48 & 4.25 & 4.37 & 3.87 & -1.11 & $-2.32 * *$ \\
\hline Offer Price (\%) & 99.80 & 99.69 & 99.94 & 99.86 & 1.14 & $5.86 * * *$ & 100.06 & 99.99 & 100.05 & 99.98 & -0.18 & -0.62 \\
\hline Effective rating launch & 15.55 & 15.00 & 15.32 & 15.00 & -1.24 & -1.11 & 19.46 & 20.00 & 19.33 & 20.00 & -1.20 & -0.76 \\
\hline Gross Fee Spread & 0.45 & 0.33 & 0.67 & 0.37 & $4.80 * * *$ & $2.56 * *$ & 0.92 & 0.75 & 0.80 & 0.48 & $-2.72 * * *$ & $-4.05 * * *$ \\
\hline Number of Underwriters & 2.94 & 3.00 & 3.34 & 3.00 & $4.73 * * *$ & $2.16^{* *}$ & 1.76 & 1.00 & 2.40 & 2.00 & $12.17 * * *$ & $10.25^{* * * *}$ \\
\hline Number of Tranches & 1.34 & 1.00 & 1.21 & 1.00 & $-3.42 * * *$ & $-3.56 * * *$ & 1.15 & 1.00 & 1.15 & 1.00 & -0.14 & 0.24 \\
\hline Past Issuer & 0.57 & 1.00 & 0.42 & 0.00 & $-5.58^{* * * *}$ & $-5.53 * * *$ & 0.74 & 1.00 & 0.64 & 1.00 & $-5.05 * * *$ & $-4.88 * * *$ \\
\hline First Time Issuer & 0.21 & 0.00 & 0.21 & 0.00 & 0.20 & 0.20 & 0.05 & 0.00 & 0.09 & 0.00 & $2.90 * * *$ & $2.71 * * *$ \\
\hline Investment Grade & 0.87 & 1.00 & 0.82 & 1.00 & $-3.00 * * *$ & $-2.87 * * *$ & 0.97 & 1.00 & 0.97 & 1.00 & 0.63 & 0.65 \\
\hline Callable & 0.24 & 0.00 & 0.21 & 0.00 & -1.21 & -1.23 & 0.05 & 0.00 & 0.06 & 0.00 & 0.91 & 0.88 \\
\hline Collateralized & 0.02 & 0.00 & 0.02 & 0.00 & 0.73 & 0.70 & 0.00 & 1.00 & 0.00 & 1.00 & 0.23 & 0.23 \\
\hline Finance Vehicle Issuer & 0.38 & 0.00 & 0.43 & 0.00 & $1.82 *$ & $1.81^{*}$ & 0.11 & 0.00 & 0.05 & 0.00 & $-4.79 * * *$ & $-5.33 * * *$ \\
\hline Private Placement & 0.08 & 0.00 & 0.06 & 0.00 & -1.01 & -1.04 & 0.04 & 0.00 & 0.10 & 0.00 & $5.46^{* * * *}$ & $4.79 * * *$ \\
\hline Euro Placement & 0.84 & 1.00 & 0.75 & 1.00 & $-4.33 * * *$ & $-4.10 * * *$ & 0.71 & 1.00 & 0.72 & 1.00 & 0.51 & 0.51 \\
\hline SEC & 0.07 & 0.00 & 0.05 & 0.00 & -1.42 & -1.49 & 0.04 & 0.00 & 0.01 & 0.00 & $-4.05 * * *$ & $-5.04 * * *$ \\
\hline Rule 144A & 0.15 & 0.00 & 0.10 & 0.00 & $-2.52 * *$ & $-2.64 * * *$ & 0.06 & 0.00 & 0.04 & 0.00 & $-1.74 *$ & $-1.83^{*}$ \\
\hline Issuer characteristics & Mean & Median & Mean & Median & $t$-value & z-value & Mean & Median & Mean & Median & $\mathrm{t}$ - value & $\mathrm{z}$ - value \\
\hline Total Assets ( $\$$ bill) & 55.46 & 31.63 & 71.90 & 36.04 & $4.10 * * *$ & 1.38 & 952.33 & 635.65 & 574.16 & 458.73 & $-10.16^{* * * *}$ & $-7.41 * * *$ \\
\hline Total Liabilities ( $\$$ bill) & 35.34 & 20.99 & 47.24 & 22.71 & $4.57 * * *$ & 1.55 & 921.91 & 621.51 & 547.73 & 444.33 & $-10.40^{* * *}$ & $-7.62 * * *$ \\
\hline Total Equity ( $\$$ bill) & 13.72 & 5.69 & 15.64 & 5.69 & 1.49 & 0.04 & 37.14 & 27.00 & 26.77 & 15.97 & $-6.71 * * *$ & $-5.47 * * *$ \\
\hline Leverage (TL/TA) & 0.66 & 0.65 & 0.66 & 0.65 & -0.19 & -0.02 & 0.95 & 0.96 & 0.95 & 0.95 & $0.38 * * *$ & $-7.19 * * *$ \\
\hline Debt Equity ratio (TL/TE) & 0.01 & 1.97 & 2.54 & 1.85 & 1.14 & 0.11 & 590.68 & 24.36 & 0.44 & 20.02 & -0.49 & $-8.01 * * *$ \\
\hline Net Income ( $\$$ bill) & 3.29 & 1.03 & 3.93 & 1.02 & $1.95^{*}$ & -0.28 & 3.16 & 1.60 & 1.43 & 0.83 & $-8.32 * * *$ & $-7.72 * * *$ \\
\hline ROA (\%) & 4.75 & 4.15 & 4.20 & 3.87 & $-2.03 * *$ & $-2.05^{* *}$ & 0.00 & 0.00 & 0.00 & 0.00 & $-3.53 * * *$ & -1.19 \\
\hline ROE $(\%)$ & 13.71 & 13.52 & 13.00 & 13.48 & -0.29 & $-1.68^{*}$ & 0.09 & 0.09 & 0.14 & 0.07 & 0.90 & $-7.54 * * *$ \\
\hline Market Capitalization Value ( $\$$ bill) & 41.17 & 16.59 & 42.29 & 17.30 & 0.37 & -0.78 & 51.52 & 46.18 & 27.72 & 17.28 & $-8.66^{* * *}$ & $-9.77 * * *$ \\
\hline Issuer Rating & 15.50 & 15.00 & 15.36 & 15.00 & -0.76 & -0.76 & 19.30 & 19.67 & 18.76 & 19.00 & $-4.59 * * *$ & $-5.65 * * *$ \\
\hline Issuer Frequency & 12.23 & 6.00 & 17.82 & 8.00 & $5.11 * * *$ & $2.01 * *$ & 98.58 & 34.00 & 130.55 & 33.00 & $4.45^{* * *}$ & -1.05 \\
\hline Issuer Parent Frequency & 15.90 & 10.00 & 24.32 & 10.00 & $6.03 * * *$ & 1.37 & 132.05 & 73.00 & 151.13 & 54.00 & $2.76^{* * *}$ & $-4.16^{* * * *}$ \\
\hline Underwriter characteristics & Mean & Median & Mean & Median & $t$-value & z-value & Mean & Median & Mean & Median & $t$ - value & $\mathrm{z}$ - value \\
\hline Average UW Market Share & 7.63 & 7.17 & 3.45 & 3.85 & $-42.13 * * *$ & $-31.26^{* * *}$ & 7.08 & 6.45 & 2.61 & 2.82 & $-55.11 * * *$ & $-38.25 * * *$ \\
\hline Market Share Worst Reputable UW & 5.23 & 5.33 & 1.47 & 1.06 & $-29.96 * * *$ & $-26.30^{* * *}$ & 6.05 & 6.03 & 1.36 & 0.87 & $-43.88^{* * *}$ & $-34.08 * * *$ \\
\hline Market Share Most Reputable UW & 10.00 & 9.83 & 5.58 & 6.23 & $-30.35 * * *$ & $-24.26 * * *$ & 8.12 & 7.74 & 3.94 & 4.01 & $-40.64 * * *$ & $-30.15 * * *$ \\
\hline
\end{tabular}


TABLE VII

PROBABILITY OF REPUTABLE MATCHING:2003-2013 (ODDS RATIO)

This table presents the odds ratio and the z-statistics for the logit regressions for non-financial and banking corporate bonds issued in Europe during 2003 - 2013 . The dependent variable is a binary variable that takes the value 1 if the bond is placed by a reputable underwriter. Issue size is the natural logarithm of the bond proceeds. The maturity variable is the natural logarithm of bond's years to mature. Callability is a dummy for bonds with a call option. The investment grade variable is a dummy taking the value 1 for Investment Grade bonds. Number of tranches reflects the tranches forming a deal. Total issue is the natural logarithm of the sum of relative issue sizes during the sample period. First issuer is a variable taking the value 1 if the bond is the first bond issued by the issuer in the last 15 years. The variable firm size is the natural logarithm of the issuer's total assets. ROA is computed as the return on assets based on the net incomes and total assets. Debt equity is a ratio of total liabilities to total equity. Syndicate size reflects the number of deal underwriters. Finance vehicle is a variable taking the value 1 if the issuer is a finance vehicle company. The dummy variable INDUSTRIAL is a dummy taking the value 1 if the issuer is a non-bank company. *,**,*** Coefficients are statistically significant different than zero at least at $10 \%, 5 \%$ and $1 \%$ levels.

\begin{tabular}{|c|c|c|c|c|c|}
\hline \multirow[b]{2}{*}{ VARIABLES } & \multirow{2}{*}{$\begin{array}{c}\text { I } \\
\text { Non- financial corporate bonds } \\
\end{array}$} & \multirow{2}{*}{$\begin{array}{c}\text { II } \\
\text { Corporate Bonds } \\
\end{array}$} & \multicolumn{3}{|c|}{ ALL } \\
\hline & & & 2003-2013 & Precrisis & Crisis \\
\hline Issue Size & $\begin{array}{l}1.918^{* * * *} \\
(0.204)\end{array}$ & $\begin{array}{c}1.502 * * * * \\
(0.104)\end{array}$ & $\begin{array}{l}1.581^{* * * *} \\
(0.0882)\end{array}$ & $\begin{array}{c}1.570^{* * * *} \\
(0111)\end{array}$ & $\begin{array}{c}1.746^{* * * *} \\
(0.130)\end{array}$ \\
\hline Maturity & $1.568^{* * * *}$ & $1.735^{* * * *}$ & $1.806 * * *$ & $1.535 * * *$ & $1.914 * * *$ \\
\hline & $(0.273)$ & $(0.216)$ & $(0.206)$ & $(0.188)$ & $(0.253)$ \\
\hline Callability & 1.308 & $0.554 * *$ & 1.014 & 1.139 & 1.156 \\
\hline & $(0.273)$ & $(0.158)$ & $(0.158)$ & $(0.192)$ & $(0.191)$ \\
\hline Investment Grade & 0.960 & $0.371^{*}$ & 0.797 & 1.013 & 0.886 \\
\hline & $(0.244)$ & $(0.196)$ & $(0.174)$ & $(0.232)$ & $(0.202)$ \\
\hline $\mathrm{N}^{\circ}$ Tranches & 1.037 & $0.736 * *$ & 0.963 & 1.039 & 0.944 \\
\hline & $(0.104)$ & $(0.112)$ & $(0.0585)$ & $(0.0742)$ & $(0.0724)$ \\
\hline Total Issue & $0.715^{* *}$ & 0.882 & $0.841^{* *}$ & $0.871^{*}$ & $0.753^{* * * *}$ \\
\hline & $(0.0970)$ & $(0.0747)$ & $(0.0615)$ & $(0.0680)$ & $(0.0743)$ \\
\hline First Issuer & $0.569 * * *$ & 0.792 & $0.664 * *$ & $0.631 * *$ & $0.588^{* * * *}$ \\
\hline & $(0.123)$ & $(0.214)$ & $(0.113)$ & $(0.120)$ & $(0.115)$ \\
\hline Firm Size & $1.329 * *$ & $1.273^{* *}$ & 1.120 & 0.988 & $1.239 * *$ \\
\hline & $(0.171)$ & $(0.151)$ & $(0.0924)$ & $(0.0887)$ & $(0.124)$ \\
\hline ROA & 0.978 & $1.193 e+11$ & 0.978 & 0.985 & 0.971 \\
\hline & $(0.0158)$ & $(2.941 \mathrm{e}+12)$ & $(0.0221)$ & $(0.0174)$ & $(0.0203)$ \\
\hline Debt to Equity & $0.996 * * *$ & 1.000 & $1.000^{* * * *}$ & $1.000 * * *$ & $1.000 * *$ \\
\hline & $(0.00112)$ & $(7.74 \mathrm{e}-06)$ & $(4.40 \mathrm{e}-06)$ & (3.35e-06) & (9.88e--06) \\
\hline Syndicate Size & $0.730^{* * *}$ & $0.648^{* * * *}$ & $0.715^{* * *}$ & $0.810^{* * * *}$ & $0.689 * * *$ \\
\hline & $(0.0424)$ & $(0.0806)$ & $(0.0490)$ & $(0.0483)$ & $(0.0442)$ \\
\hline Finance Vehicle & $0.670^{* *}$ & $3.223 *$ & 0.744 & $0.619 * *$ & 0.695 \\
\hline & $(0.136)$ & (1.980) & $(0.199)$ & $(0.145)$ & $(0.182)$ \\
\hline INDUSTRIAL & & & $1.504 *$ & 1.172 & $2.102 * *$ \\
\hline & & & $(0.361)$ & $(0.331)$ & $(0.616)$ \\
\hline Constant & $\begin{array}{c}0.00265^{* * *} \\
(0.00267)\end{array}$ & $\begin{array}{c}0.0131 * * * \\
(0.0151)\end{array}$ & $\begin{array}{c}0.0136^{* * * *} \\
(0.00932)\end{array}$ & $\begin{array}{c}0.0249^{* * * *} \\
(0.0177)\end{array}$ & $\begin{array}{c}0.00464 * * * \\
(0.00403)\end{array}$ \\
\hline Year & Yes & Yes & Yes & Yes & Yes \\
\hline Industries & Yes & & 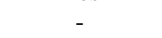 & . & 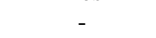 \\
\hline Countries & Yes & Yes & Yes & Yes & Yes \\
\hline Standard Errors & Cluster Issuer & Cluster Issuer & Cluster Issuer & Cluster Issuer & Cluster Issuer \\
\hline Pseudo $R^{2}$ & 0.2469 & 0.2220 & 0.1828 & 0.1586 & 0.2231 \\
\hline Log-Likelihood & -726.7436 & -1074.348 & -1918.3611 & -1249.8936 & -1408.1241 \\
\hline p-value $\left(\mathrm{chi}^{2)}\right)$ & 0.00 & 0.00 & 0.00 & 0.00 & 0.00 \\
\hline Observations & 1,490 & 2,197 & 3,687 & 2,237 & 2,940 \\
\hline
\end{tabular}


TABLE VIII

UNIVARIATE STATISTICS BY ISSUE DATE: PRECRISIS vs. CRISIS

This table reports the descriptive statistics for the sample of corporate bonds issued in Europe distinguishing on the issue date. Mean and median values are reported for deals issued before (pre-crisis) and after (crisis) the 30th June 2007. The statistics for deals underwritten by reputable underwriter are also reported. We consider a deal as reputable placed if the underwriter or the syndicate is included in the top 7 of underwriter table leagues provided annually by Dealogic Capital Market according to the market share. We have reported variables that refer specifically to the bond, the issuer and the underwriter. We use two tails t-test for difference in means between the two groups of corporate bonds (pre-crisis vs. crisis) and Wilcoxon Mann- Whitney test is used for medians (pre-crisis vs. crisis). *,**,*** Different is significant at less than $10 \%, 5 \%, 1 \%$ level.

\begin{tabular}{|c|c|c|c|c|c|c|c|c|c|c|}
\hline \multirow{3}{*}{ Bond Characteristics } & \multicolumn{6}{|c|}{ CORPORATE BONDS (ALL) } & \multirow{2}{*}{\multicolumn{2}{|c|}{$\begin{array}{c}\text { Precrisis } \\
\text { Reputable Underwriter }\end{array}$}} & \multirow{2}{*}{\multicolumn{2}{|c|}{\begin{tabular}{|c|} 
Crisis \\
Reputable Underwriter
\end{tabular}}} \\
\hline & \multicolumn{2}{|c|}{ Precrisis } & \multicolumn{2}{|c|}{ Crisis } & \multirow{2}{*}{$\frac{\mathrm{t} \text {-test }}{\mathrm{t} \text { - value }}$} & \multirow{2}{*}{$\begin{array}{c}\mathrm{z} \text {-test } \\
\mathrm{z} \text { - value }\end{array}$} & & & & \\
\hline & Mean & Median & Mean & Median & & & Mean & Median & Mean & Median \\
\hline 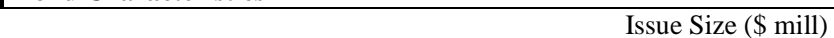 & 444.78 & 241.38 & 910.05 & 630.87 & $17.48^{* * * *}$ & $16.91 * * *$ & 523.69 & 326.79 & 910.05 & 630.87 \\
\hline Maturity (years) & 6.92 & 5.55 & 6.09 & 5.00 & $-5.28 * * *$ & $-5.62 * * *$ & 7.45 & 6.93 & 6.09 & 5.00 \\
\hline Yield (\%) & 4.70 & 4.43 & 4.49 & 4.07 & $-2.31 * *$ & $-2.75 * * *$ & 4.45 & 4.43 & 4.49 & 4.07 \\
\hline Coupon (\%) & 4.73 & 4.38 & 4.46 & 4.00 & $-3.31 * * *$ & $-3.31 * * *$ & 4.53 & 4.50 & 4.46 & 4.00 \\
\hline Offer Price (\%) & 100.08 & 100.00 & 99.95 & 99.89 & $-2.69 * * *$ & $-5.37 * * *$ & 100.14 & 99.94 & 99.95 & 99.89 \\
\hline Effective rating launch & 18.75 & 20.00 & 17.49 & 18.00 & $-10.09 * * *$ & $-12.44 * * *$ & 18.45 & 19.00 & 17.49 & 18.00 \\
\hline Gross Fee Spread & 0.96 & 0.76 & 0.52 & 0.28 & $-14.18 * * *$ & $-14.76 * * *$ & 0.90 & 0.75 & 0.52 & 0.28 \\
\hline Number of Underwriters & 1.84 & 2.00 & 2.93 & 3.00 & $24.34 * * *$ & $19.49 * * *$ & 1.95 & 2.00 & 2.93 & 3.00 \\
\hline Past Issuer & 0.73 & 1.00 & 0.54 & 1.00 & $-11.99^{* * *}$ & $-11.30^{* * *}$ & 0.77 & 1.00 & 0.54 & 1.00 \\
\hline First Time Issuer & 0.11 & 0.00 & 0.14 & 0.00 & $2.41 * *$ & $2.33^{* *}$ & 0.11 & 0.00 & 0.14 & 0.00 \\
\hline Investment Grade & 0.93 & 1.00 & 0.92 & 1.00 & -1.57 & -1.52 & 0.92 & 1.00 & 0.92 & 1.00 \\
\hline Callable & 0.11 & 0.00 & 0.13 & 0.00 & 1.40 & 1.37 & 0.11 & 0.00 & 0.13 & 0.00 \\
\hline Collateralized & 0.01 & 0.00 & 0.01 & 0.00 & $2.59 * * *$ & $2.22 * *$ & 0.01 & 0.00 & 0.01 & 0.00 \\
\hline Finance Vehicle Issuer & 0.21 & 0.00 & 0.20 & 0.00 & -0.39 & -0.39 & 0.21 & 0.00 & 0.20 & 0.00 \\
\hline Private Placement & 0.09 & 0.00 & 0.07 & 0.00 & -1.39 & -1.43 & 0.04 & 0.00 & 0.07 & 0.00 \\
\hline Euro Placement & 0.70 & 1.00 & 0.76 & 1.00 & $3.56 * * *$ & $3.64 * * *$ & 0.74 & 1.00 & 0.76 & 1.00 \\
\hline SEC & 0.02 & 0.00 & 0.04 & 0.00 & $3.71 * * *$ & $3.28 * * *$ & 0.02 & 0.00 & 0.04 & 0.00 \\
\hline Rule $144 \mathrm{~A}$ & 0.06 & 0.00 & 0.09 & 0.00 & $3.38 * * *$ & $3.15^{* * * *}$ & 0.07 & 0.00 & 0.09 & 0.00 \\
\hline \begin{tabular}{|l} 
Issuer Characteristics \\
\end{tabular} & Mean & Median & Mean & Median & $t$ - value & $\mathrm{z}$ - value & Mean & Median & Mean & Median \\
\hline Total Equity ( $\$$ bill) & 15.37 & 8.17 & 27.71 & 11.37 & $15.06 * * *$ & $9.67 * * *$ & 15.08 & 6.04 & 27.71 & 11.37 \\
\hline Leverage (TL/TA) & 0.86 & 0.95 & 0.82 & 0.93 & $-4.71 * * *$ & $-8.82 * * *$ & 0.84 & 0.95 & 0.82 & 0.93 \\
\hline Debt Equity ratio (TL/TE) & 373.24 & 17.94 & 254.03 & 13.70 & -0.59 & $-9.59 * * *$ & 507.02 & 17.87 & 254.03 & 13.70 \\
\hline Net income ( $\$$ bill) & 2.25 & 0.75 & 2.87 & 1.25 & $3.79 * * *$ & $5.10 * * *$ & 2.20 & 0.82 & 2.87 & 1.25 \\
\hline ROA (\%) & 1.63 & 0.00 & 1.84 & 0.00 & 1.52 & $2.78 * * *$ & 1.70 & 0.00 & 1.84 & 0.00 \\
\hline $\operatorname{ROE}(\%)$ & 4.39 & 0.12 & 5.81 & 0.12 & 1.25 & 0.07 & 4.25 & 0.13 & 5.81 & 0.12 \\
\hline Market Capitalization Value ( $\$$ bill) & 49.37 & 26.04 & 37.79 & 18.28 & $-3.93^{* * *}$ & $-3.19 * * *$ & 42.08 & 21.79 & 37.79 & 18.28 \\
\hline Issuer Rating & 18.83 & 20.00 & 17.19 & 17.67 & $-12.95 * * *$ & $-16.89 * * *$ & 18.41 & 19.67 & 17.19 & 17.67 \\
\hline Issuer Frequency & 106.42 & 22.00 & 66.46 & 14.50 & $-7.35 * * *$ & $-7.08 * * *$ & 93.11 & 16.00 & 66.46 & 14.50 \\
\hline Issuer Parent Frequency & 131.79 & 63.00 & 80.01 & 29.00 & $-9.62 * * *$ & $-10.65 * * *$ & 118.28 & 63.00 & 80.01 & 29.00 \\
\hline \begin{tabular}{|l|} 
Underwriter Characteristics \\
\end{tabular} & Mean & Median & Mean & Median & $t$ - value & $\mathrm{z}$ - value & Mean & Median & Mean & Median \\
\hline Average UW Market Share & 5.08 & 5.09 & 4.12 & 4.06 & $-9.55 * * *$ & $-9.55^{* * *}$ & 7.52 & 7.22 & 4.12 & 4.06 \\
\hline Market Share Worst Reputable UW & 3.86 & 3.23 & 2.42 & 1.37 & $-14.15 * * *$ & $-15.55 * * *$ & 6.00 & 5.92 & 2.42 & 1.37 \\
\hline Market Share Most Reputable UW & 6.39 & 6.32 & 5.88 & 6.23 & $-4.12 * * *$ & $-4.75 * * *$ & 9.05 & 9.04 & 5.88 & 6.23 \\
\hline
\end{tabular}


TABLE IX

PROBABILITY OF REPUTABLE MATCHING BY ISSUE DATE: PRECRISIS vs. CRISIS (ODDS RATIO)

This table presents the odds ratio and the z-statistics for the logit regressions for corporate bond issued in Europe during 2003 - 2013. The dependent variable is a binary variable that takes the value 1 if the bond is placed by a reputable underwriter. Issue size is the natural logarithm of the bond proceeds. The maturity variable is the natural logarithm of bond's years to mature. Callability is a dummy for bonds with a call option. The investment grade variable is a dummy taking the value 1 for Investment Grade bonds. Number of tranches reflects the tranches forming a deal. Total issue is the natural logarithm of the sum of relative issue sizes during the sample period. First issuer is a variable taking the value 1 if the bond is the first bond issued by the issuer in the last 15 years. The variable firm size is the natural logarithm of the issuer's total assets. ROA is computed as the return on assets based on the net incomes and total assets. Debt equity is a ratio of total liabilities to total equity. Syndicate size reflects the number of deal underwriters. Finance vehicle is a variable taking the value 1 if the issuer is a finance vehicle company. The dummy variable INDUSTRIAL is a dummy taking the value 1 if the issuer is a non-bank company. Precrisis comprises the period of time from 01/01/03 - 30/06/07. Subprime crisis starts 01/07/07 until 30/09/08. The banking crisis window comprises 01/10/08 - 30/06/10. Since 01/07/10 we consider the period as the European sovereign debt crisis. *, **, *** Coefficients are statistically significant different than zero at least at $10 \%, 5 \%$ and $1 \%$ levels.

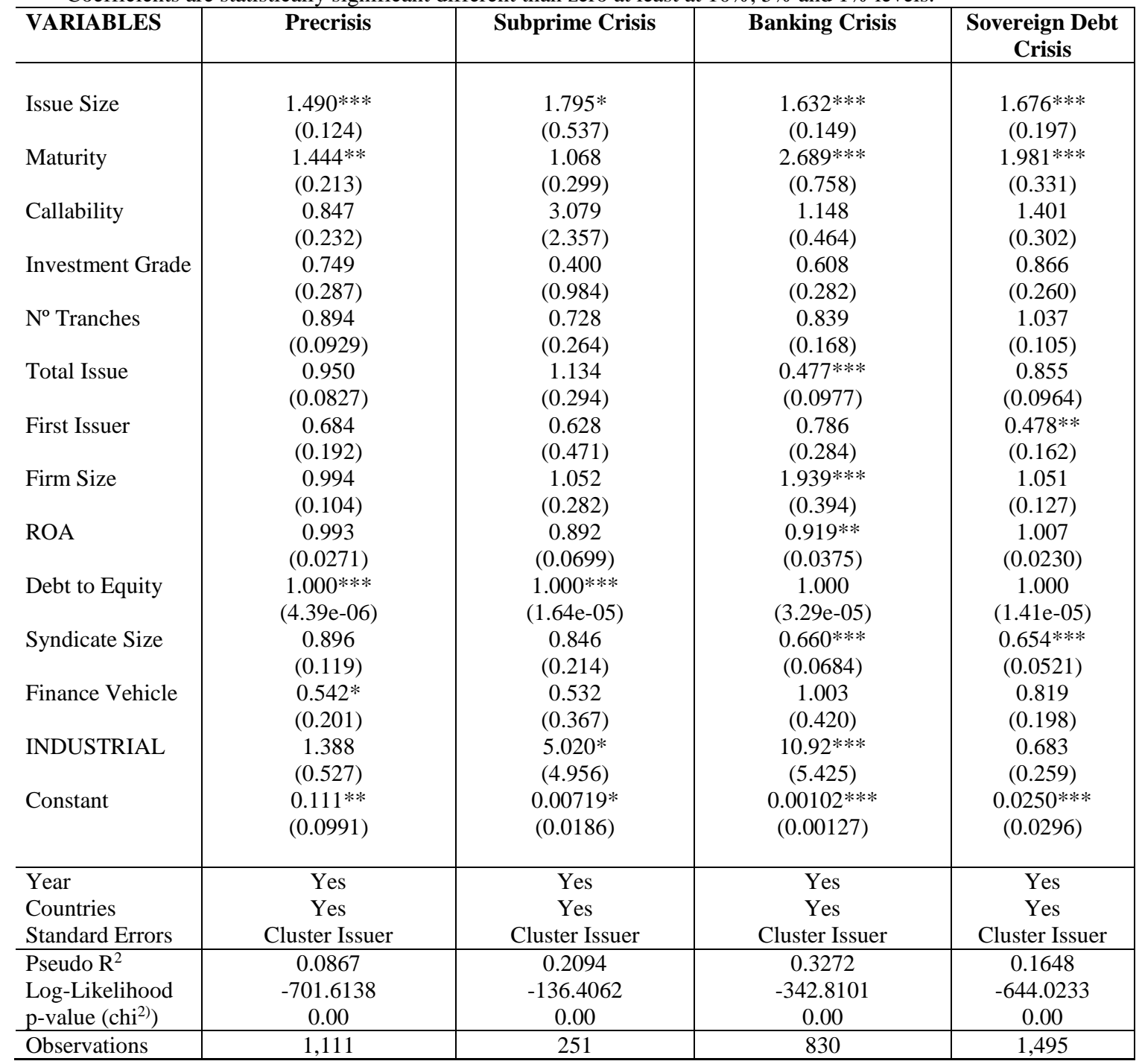




\section{TABLE X}

\section{PROBABILITY OF REPUTABLE MATCHING FOR NON-FINANCIAL AND BANKING \\ CORPORATE BONDS (LOGIT COEFFICIENTS)}

This table presents the logit coefficients and the z-statistics (in parenthesis) for the logit regressions for nonfinancial and banking corporate bonds issued in Europe during 2003-2013. The dependent variable is a binary variable that takes the value 1 if the bond is placed by a reputable underwriter. Issue size is the natural logarithm of the bond proceeds. The maturity variable is the natural logarithm of bond's years to mature. Callability is a dummy for bonds with a call option. The investment grade variable is a dummy taking the value 1 for Investment Grade bonds. Number of tranches reflects the tranches forming a deal. Total issue is the natural logarithm of the sum of relative issue sizes during the sample period. First issuer is a variable taking the value 1 if the bond is the first bond issued by the issuer in the last 15 years. The variable firm size is the natural logarithm of issuer's total assets. ROA is computed as the return on assets based on the net incomes and total assets. Debt equity is a ratio of total liabilities to total equity. Industries dummies are based on SIC classification. Syndicate size reflects the number of deal underwriters. Finance vehicle is a variable taking the value 1 if the issuer is a finance vehicle company. Z-statistics are based on issuer clustered standard errors. A constant term (not reported) is included in all regressions. $* * *, * * *$ Coefficients are statistically significant different than zero at least at $10 \%, 5 \%$ and $1 \%$ levels.

\begin{tabular}{|c|c|c|c|c|c|c|}
\hline \multirow[b]{2}{*}{ VARIABLES } & \multicolumn{4}{|c|}{ Non-Financial Corporate Bonds } & \multicolumn{2}{|c|}{ Banking corporate bond } \\
\hline & $\mathbf{I}$ & II & III & IV & I & II \\
\hline Issue Size & $\begin{array}{c}0.721 * * * \\
(0.117)\end{array}$ & $\begin{array}{c}0.645 * * * \\
(0.105)\end{array}$ & $\begin{array}{c}0.716 * * * \\
(0.108)\end{array}$ & $\begin{array}{c}0.652 * * * \\
(0.106)\end{array}$ & $\begin{array}{c}0.434 * * * \\
(0.0769)\end{array}$ & $\begin{array}{c}0.407 * * * \\
(0.0694)\end{array}$ \\
\hline Maturity & $\begin{array}{l}0.426 * * \\
(0.209)\end{array}$ & $\begin{array}{l}0.494 * * \\
(0.215)\end{array}$ & $\begin{array}{l}0.410 * * \\
(0.169)\end{array}$ & $\begin{array}{c}0.450 * * * \\
(0.174)\end{array}$ & $\begin{array}{c}0.626 * * * \\
(0.135)\end{array}$ & $\begin{array}{c}0.551 * * * \\
(0.125)\end{array}$ \\
\hline Callability & $\begin{array}{l}0.367 * \\
(0.203)\end{array}$ & $\begin{array}{l}0.382 * \\
(0.214)\end{array}$ & $\begin{array}{c}0.248 \\
(0.200)\end{array}$ & $\begin{array}{c}0.268 \\
(0.209)\end{array}$ & $\begin{array}{l}-0.573^{*} \\
(0.297)\end{array}$ & $\begin{array}{c}-0.590 * * \\
(0.284)\end{array}$ \\
\hline Investment Grade & $\begin{array}{c}0.257 \\
(0.261)\end{array}$ & $\begin{array}{c}0.111 \\
(0.278)\end{array}$ & $\begin{array}{l}0.0861 \\
(0.261)\end{array}$ & $\begin{array}{l}-0.0409 \\
(0.254)\end{array}$ & $\begin{array}{c}-1.345 * * \\
(0.551)\end{array}$ & $\begin{array}{l}-0.990^{*} \\
(0.528)\end{array}$ \\
\hline $\mathrm{N}^{\mathrm{o}}$ Tranches & $\begin{array}{c}0.103 \\
(0.105)\end{array}$ & $\begin{array}{c}0.0912 \\
(0.0976)\end{array}$ & $\begin{array}{l}0.0416 \\
(0.101)\end{array}$ & $\begin{array}{c}0.0364 \\
(0.0999)\end{array}$ & $\begin{array}{l}-0.249 * \\
(0.148)\end{array}$ & $\begin{array}{c}-0.307 * * \\
(0.152)\end{array}$ \\
\hline Total Issue & $\begin{array}{l}-0.185 \\
(0.147)\end{array}$ & $\begin{array}{l}-0.236^{*} \\
(0.138)\end{array}$ & $\begin{array}{c}-0.337 * * \\
(0.137)\end{array}$ & $\begin{array}{c}-0.336 * * \\
(0.136)\end{array}$ & $\begin{array}{c}-0.197 * * * \\
(0.0751)\end{array}$ & $\begin{array}{l}-0.125 \\
(0.0846)\end{array}$ \\
\hline First Issuer & $\begin{array}{c}-0.728 * * * \\
(0.220)\end{array}$ & $\begin{array}{c}-0.634 * * * \\
(0.209)\end{array}$ & $\begin{array}{c}-0.693 * * * \\
(0.223)\end{array}$ & $\begin{array}{c}-0.564 * * * \\
(0.215)\end{array}$ & $\begin{array}{l}-0.311 \\
(0.276)\end{array}$ & $\begin{array}{l}-0.233 \\
(0.270)\end{array}$ \\
\hline Firm Size & $\begin{array}{l}-0.0101 \\
(0.141)\end{array}$ & $\begin{array}{c}0.219 \\
(0.134)\end{array}$ & $\begin{array}{c}0.115 \\
(0.128)\end{array}$ & $\begin{array}{c}0.284 * * \\
(0.129)\end{array}$ & $\begin{array}{c}0.416 * * * \\
(0.126)\end{array}$ & $\begin{array}{c}0.242 * * \\
(0.119)\end{array}$ \\
\hline ROA & $\begin{array}{l}-0.0114 \\
(0.0171)\end{array}$ & $\begin{array}{l}-0.00616 \\
(0.0164)\end{array}$ & $\begin{array}{l}-0.0250 \\
(0.0169)\end{array}$ & $\begin{array}{l}-0.0219 \\
(0.0162)\end{array}$ & $\begin{array}{c}22.09 \\
(21.39)\end{array}$ & $\begin{array}{l}25.51 \\
(24.64)\end{array}$ \\
\hline Debt to Equity & $\begin{array}{c}-0.00371 * * * \\
(0.00115)\end{array}$ & $\begin{array}{c}-0.00431 * * * \\
(0.00122)\end{array}$ & $\begin{array}{c}-0.00344 * * * \\
(0.00111)\end{array}$ & $\begin{array}{c}-0.00366^{* * * *} \\
(0.00112)\end{array}$ & $\begin{array}{c}8.49 \mathrm{e}-06 \\
(8.30 \mathrm{e}-06)\end{array}$ & $\begin{array}{c}6.80 \mathrm{e}-06 \\
(7.74 \mathrm{e}-06)\end{array}$ \\
\hline Syndicate Size & $\begin{array}{c}-0.293 * * * \\
(0.0588)\end{array}$ & $\begin{array}{c}-0.314 * * * \\
(0.0557)\end{array}$ & $\begin{array}{c}-0.284 * * * \\
(0.0610)\end{array}$ & $\begin{array}{c}-0.314 * * * \\
(0.0580)\end{array}$ & $\begin{array}{c}-0.512 * * * \\
(0.133)\end{array}$ & $\begin{array}{c}-0.433 * * * \\
(0.124)\end{array}$ \\
\hline Finance Vehicle & $\begin{array}{c}-0.412 * * \\
(0.199)\end{array}$ & $\begin{array}{l}-0.303^{*} \\
(0.191)\end{array}$ & $\begin{array}{c}-0.587 * * * \\
(0.215)\end{array}$ & $\begin{array}{c}-0.400 * * \\
(0.203)\end{array}$ & $\begin{array}{c}1.163 \\
(0.712)\end{array}$ & $\begin{array}{l}1.170^{*} \\
(0.614)\end{array}$ \\
\hline Year & Yes & Yes & Yes & Yes & Yes & Yes \\
\hline Industries & No & Yes & No & Yes & - & - \\
\hline Countries & No & No & Yes & Yes & No & Yes \\
\hline Standard Errors & $\begin{array}{l}\text { Cluster } \\
\text { Issuer }\end{array}$ & $\begin{array}{l}\text { Cluster } \\
\text { Issuer }\end{array}$ & $\begin{array}{l}\text { Cluster } \\
\text { Issuer }\end{array}$ & $\begin{array}{l}\text { Cluster } \\
\text { Issuer }\end{array}$ & $\begin{array}{l}\text { Cluster } \\
\text { Issuer }\end{array}$ & $\begin{array}{l}\text { Cluster } \\
\text { Issuer }\end{array}$ \\
\hline Pseudo $\mathrm{R}^{2}$ & 0.1951 & 0.2206 & 0.2282 & 0.2469 & 0.2092 & 0.2220 \\
\hline Log-Likelihood & -776.71 & -752.16 & -744.75 & -726.74 & -1092.06 & -1074.35 \\
\hline p-value $\left(\mathrm{chi}^{2)}\right)$ & 0.00 & 0.00 & 0.00 & 0.00 & 0.00 & 0.00 \\
\hline Predicted Prob. & 0.35 & 0.35 & 0.35 & 0.35 & 0.32 & 0.32 \\
\hline Observations & 1,490 & 1,490 & 1,490 & 1,490 & 2,197 & 2,197 \\
\hline
\end{tabular}




\section{TABLE XI}

\section{MARGINAL EFFECTS ON THE PROBABILITY OF REPUTABLE MATCHING FOR NON-FINANCIAL AND}

\section{BANKS CORPORATE BONDS}

This table presents the marginal effects for the logit regressions for non-financial and banks corporate bonds issued in Europe during 2003-2013. The dependent variable is a binary variable that takes the value 1 if the bond is underwritten by a reputable underwriter. Issue size is the natural logarithm of the bond proceeds. The maturity variable is the natural logarithm of bond's years to mature. Callability is a dummy for bonds with a call option. The investment grade variable is a dummy taking the value 1 for Investment Grade bonds. Number of tranches reflects the tranches forming a deal. Total issue is the natural logarithm of the sum of relative issue sizes during the sample period. First issuer is a variable taking the value 1 if the bond is the first bond issued by the issuer in the last 15 years. The variable firm size is the natural logarithm of the issuer's total assets. ROA is computed as the return on assets based on the net incomes and total assets. Debt equity is a ratio of total liabilities to total equity. Syndicate size reflects the number of deal underwriters. Finance vehicle is a variable taking the value 1 if the issuer is a finance vehicle company. Industries dummies are based on SIC classification. A constant term (not reported) is included in all regressions. MEM presents the Marginal Effects at Means. AME presents the Average Marginal Effects. *, **,*** Coefficients are statistically significant different than zero at least at $10 \%, 5 \%$ and $1 \%$ levels.

\begin{tabular}{|c|c|c|c|c|c|c|c|c|c|c|}
\hline \multirow[b]{3}{*}{ VARIABLES } & \multirow{2}{*}{\multicolumn{2}{|c|}{ NON-FINANCIAL }} & \multirow{2}{*}{\multicolumn{2}{|c|}{ BANKS }} & \multirow{2}{*}{\multicolumn{3}{|c|}{$\begin{array}{c}\begin{array}{c}\text { MEM: Marginal Effects } \\
\text { at Means }\end{array} \\
\text { Non-financial - Banks }\end{array}$}} & \multirow{2}{*}{\multicolumn{3}{|c|}{$\begin{array}{l}\text { AME: Average Marginal } \\
\text { Effects } \\
\text { Non-financial - Banks }\end{array}$}} \\
\hline & & & & & & & & & & \\
\hline & MEM & AME & MEM & AME & Difference & $\begin{array}{c}\text { Diff in } \\
\%\end{array}$ & Ratio & Difference & $\begin{array}{c}\text { Diff in } \\
\%\end{array}$ & Ratio \\
\hline Issue Size & $\begin{array}{c}0.136 * * * \\
(0.0222)\end{array}$ & $\begin{array}{c}0.104 * * * \\
(0.0165)\end{array}$ & $\begin{array}{c}0.0800^{* * * *} \\
(0.0145)\end{array}$ & $\begin{array}{c}0.0653 * * * \\
(0.0102)\end{array}$ & 0.056 & 5.60 & 1.70 & 0.0387 & 3.87 & 1.59 \\
\hline Maturity & $\begin{array}{c}0.0942 * * * \\
(0.0371)\end{array}$ & $\begin{array}{c}0.0722 * * * \\
(0.0282)\end{array}$ & $\begin{array}{c}0.108 * * * \\
(0.0249)\end{array}$ & $\begin{array}{c}0.0885 * * * \\
(0.0203)\end{array}$ & -0.0138 & -1.38 & 0.87 & -0.0163 & -1.63 & 0.82 \\
\hline Callability & $\begin{array}{c}0.0561 \\
(0.0438)\end{array}$ & $\begin{array}{c}0.0430 \\
(0.0333)\end{array}$ & $\begin{array}{l}-0.116 * * \\
(0.0560)\end{array}$ & $\begin{array}{c}-0.0948 * * \\
(0.0455)\end{array}$ & 0.1721 & 17.21 & -0.48 & 0.1378 & 13.78 & -0.45 \\
\hline Investment Grade & $\begin{array}{r}-0.00857 \\
(0.0532)\end{array}$ & $\begin{array}{r}-0.00656 \\
(0.0408)\end{array}$ & $\begin{array}{l}-0.195^{*} \\
(0.103)\end{array}$ & $\begin{array}{l}-0.159^{*} \\
(0.0834)\end{array}$ & 0.18643 & 18.64 & 0.04 & 0.15244 & 15.24 & 0.04 \\
\hline $\mathrm{N}^{\mathrm{o}}$ Tranches & $\begin{array}{l}0.00761 \\
(0.0209)\end{array}$ & $\begin{array}{l}0.00583 \\
(0.0160)\end{array}$ & $\begin{array}{c}-0.0604 * * \\
(0.0300)\end{array}$ & $\begin{array}{c}-0.0493 * * \\
(0.0238)\end{array}$ & 0.06801 & 6.80 & -0.13 & 0.05513 & 5.51 & -0.12 \\
\hline Total Issue & $\begin{array}{c}-0.0703 * * \\
(0.0282)\end{array}$ & $\begin{array}{c}-0.0539 * * \\
(0.0215)\end{array}$ & $\begin{array}{c}-0.0247 \\
(0.0166)\end{array}$ & $\begin{array}{l}-0.0202 \\
(0.0135)\end{array}$ & -0.0456 & -4.56 & 2.85 & -0.0337 & -3.37 & 2.67 \\
\hline First Issuer & $\begin{array}{c}-0.118 * * * \\
(0.0451)\end{array}$ & $\begin{array}{c}-0.0905 * * * \\
(0.0342)\end{array}$ & $\begin{array}{l}-0.0459 \\
(0.0534)\end{array}$ & $\begin{array}{l}-0.0375 \\
(0.0434)\end{array}$ & -0.0721 & -7.21 & 2.57 & -0.053 & -5.30 & 2.41 \\
\hline Firm Size & $\begin{array}{c}0.0595 * * \\
(0.0268)\end{array}$ & $\begin{array}{c}0.0456 * * \\
(0.0205)\end{array}$ & $\begin{array}{c}0.0475 * * \\
(0.0235)\end{array}$ & $\begin{array}{c}0.0388 * * \\
(0.0186)\end{array}$ & 0.012 & 1.20 & 1.25 & 0.0068 & 0.68 & 1.18 \\
\hline ROA & $\begin{array}{l}-0.00458 \\
(0.00336)\end{array}$ & $\begin{array}{l}-0.00351 \\
(0.00257)\end{array}$ & $\begin{array}{l}5.017 \\
(4.828)\end{array}$ & $\begin{array}{l}4.098 \\
(3.980)\end{array}$ & -5.02158 & -502.16 & 0.00 & -4.10151 & -410.15 & 0.00 \\
\hline Debt to Equity & $\begin{array}{c}-0.00076^{* * * *} \\
(0.000234)\end{array}$ & $\begin{array}{c}-0.00058 * * * \\
(0.000179)\end{array}$ & $\begin{array}{c}1.34 \mathrm{e}-06 \\
(1.51 \mathrm{e}-06)\end{array}$ & $\begin{array}{c}1.09 \mathrm{e}-06 \\
(1.24 \mathrm{e}-06)\end{array}$ & -0.00076 & -0.08 & -570.90 & -0.00058 & -0.06 & -537.61 \\
\hline Syndicate Size & $\begin{array}{c}-0.0658 * * * \\
(0.0125)\end{array}$ & $\begin{array}{c}-0.0504 * * * \\
(0.00941)\end{array}$ & $\begin{array}{c}-0.0852 * * * \\
(0.0262)\end{array}$ & $\begin{array}{c}-0.0696 * * * \\
(0.0204)\end{array}$ & 0.0194 & 1.51 & 0.77 & 0.0192 & 1.92 & 0.72 \\
\hline Finance Vehicle & $\begin{array}{c}-0.0837 * * \\
(0.0419)\end{array}$ & $\begin{array}{c}-0.0641 * * \\
(0.0323)\end{array}$ & $\begin{array}{l}0.230 * \\
(0.122)\end{array}$ & $\begin{array}{c}0.188^{*} \\
(0.0978)\end{array}$ & -0.3137 & -30.52 & -0.36 & -0.2521 & -25.21 & -0.34 \\
\hline $\begin{array}{l}\text { Year } \\
\text { Industries } \\
\text { Countries } \\
\text { Standard Errors }\end{array}$ & $\begin{array}{c}\text { Yes } \\
\text { Yes } \\
\text { Yes } \\
\text { Cluster Issuer }\end{array}$ & $\begin{array}{c}\text { Yes } \\
\text { Yes } \\
\text { Yes } \\
\text { Cluster Issuer }\end{array}$ & $\begin{array}{c}\text { Yes } \\
- \\
\text { Yes } \\
\text { Cluster } \\
\text { Issuer }\end{array}$ & $\begin{array}{c}\text { Yes } \\
- \\
\text { Yes } \\
\text { Cluster } \\
\text { Issuer }\end{array}$ & & & & & & \\
\hline $\begin{array}{l}\text { Pseudo R }{ }^{2} \\
\text { Log-Likelihood } \\
\text { p-value }\left(\mathrm{chi}^{2)}\right) \\
\text { Observations }\end{array}$ & $\begin{array}{r}0.2 \\
-72 \\
0 . \\
1,4\end{array}$ & & $\begin{array}{r}0.2 \\
-107\end{array}$ & $\begin{array}{l}20 \\
4.35 \\
0 \\
97\end{array}$ & & & & & & \\
\hline
\end{tabular}


FIGURE III

MARGINAL EFFECTS ON REPUTABLE MATCHING BY BOND SIZE, ISSUER SIZE AND MATURITY
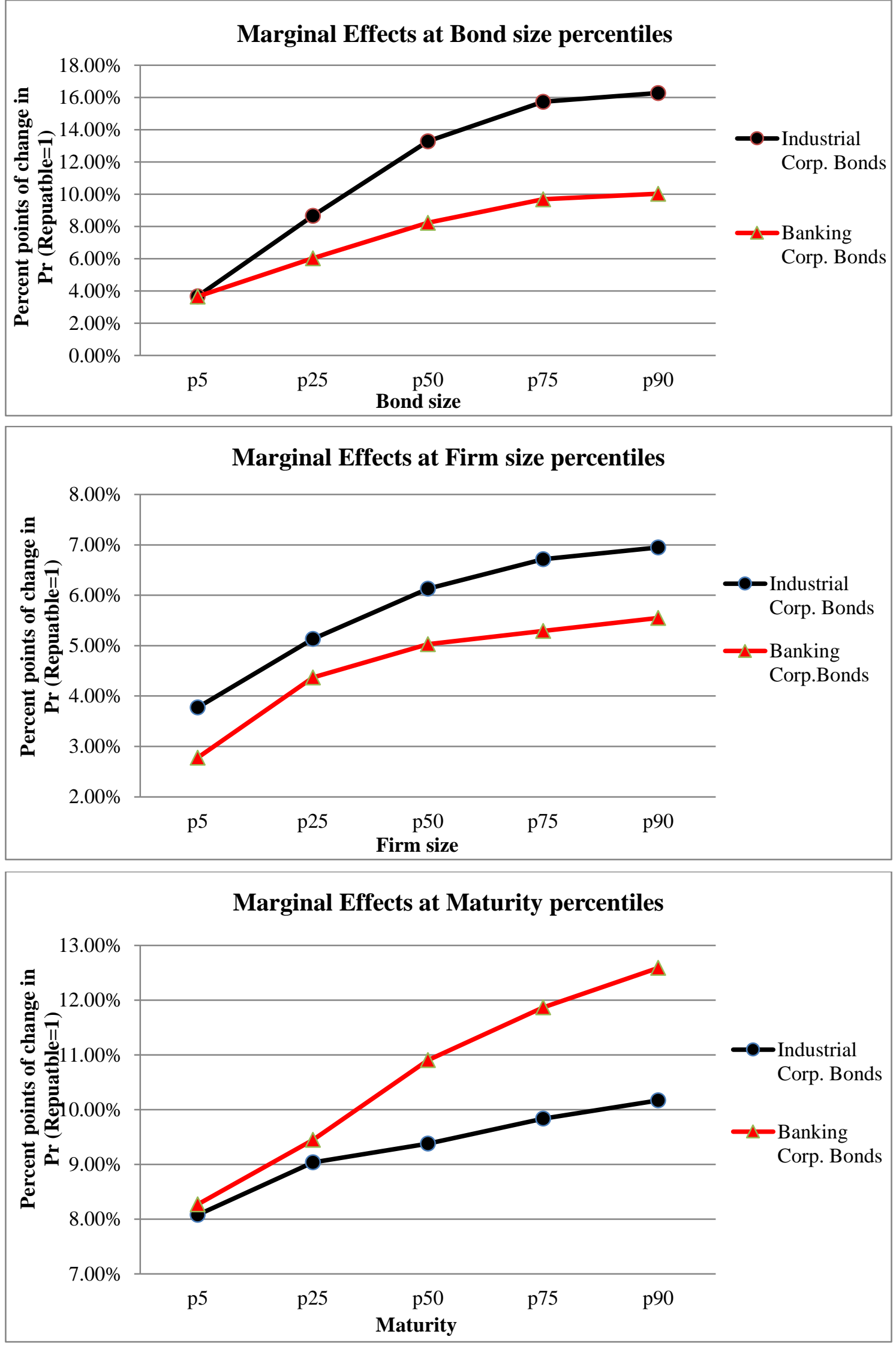
TABLE XII

ROBUSTNESS ON THE PROBABILITY OF REPUTABLE MATCHING: SUB-SAMPLE OF BONDS OF INDUSTRIAL FIRMS AND BANKS THAT ISSUED AT LEAST ONCE

IN THE PRECRISIS AND CRISIS PERIODS (ODDS RATIO)

This table presents the odds ratio and the z-statistics for the logit regressions for corporate bond issued in Europe during 2003 - 2013 for the sub-sample of bonds of industrial firms and banks that issued at least once in both periods: precrisis and the crisis. The dependent variable is a binary variable that takes the value 1 if the bond is placed by a reputable underwriter. Issue size is the natural logarithm of the bond proceeds. The maturity variable is the natural logarithm of bond's years to mature. Callability is a dummy for bonds with a call option. The investment grade variable is a dummy taking the value 1 for Investment Grade bonds. Number of tranches reflects the tranches forming a deal. Total issue is the natural logarithm of the sum of relative issue sizes during the sample period. First issuer is a variable taking the value 1 if the bond is the first bond issued by the issuer in the last 15 years. The variable firm size is the natural logarithm of the issuer's total assets. ROA is computed as the return on assets based on the net incomes and total assets. Debt equity is a ratio of total liabilities to total equity. Syndicate size reflects the number of deal underwriters. Finance vehicle is a variable taking the value 1 if the issuer is a finance vehicle company. The dummy variable INDUSTRIAL is a dummy taking the value 1 if the issuer is a non-bank company. Precrisis comprises the period of time from 01/01/03 - 30/06/07. Subprime crisis starts 01/07/07 until 30/09/08. The banking crisis window comprises 01/10/08 - 30/06/10. Since $01 / 07 / 10$ we consider the period as the European sovereign debt crisis. A constant term (not reported) is included in all regressions. Z-statistics are based on robust standard errors. *,**, *** Coefficients are statistically significant different than zero at least at $10 \%, 5 \%$ and $1 \%$ levels.

\begin{tabular}{|c|c|c|c|c|c|}
\hline VARIABLES & $2003-2013$ & Precrisis & Subprime crisis & Banking crisis & Sovereign Debt crisis \\
\hline Issue Size & $\begin{array}{c}1.630 * * * \\
(0.0711)\end{array}$ & $\begin{array}{c}1.526 * * * * \\
(0.106)\end{array}$ & $\begin{array}{c}1.919 * * * \\
(0.407)\end{array}$ & $\begin{array}{c}1.693 * * * \\
(0193)\end{array}$ & $1.731 * * *$ \\
\hline Maturity & $1.653 * * *$ & $\begin{array}{l}(0.106) \\
1.369 * *\end{array}$ & $\begin{array}{c}(0.407) \\
0.828\end{array}$ & $\begin{array}{l}(0.193) \\
2625 * * *\end{array}$ & $(0.161)$ \\
\hline & $(0.149)$ & $(0.192)$ & $\begin{array}{l}0.020 \\
(0.219)\end{array}$ & $\begin{array}{c}2.635^{* * * * *} \\
(0.641)\end{array}$ & $1.978^{* * * *}$ \\
\hline Callability & 0.930 & 0.883 & 2.165 & $\begin{array}{c}(0.041) \\
1.247\end{array}$ & $(0.540)$ \\
\hline & $(0.151)$ & $(0.234)$ & $(1.738)$ & $(0.617)$ & $\begin{array}{l}1.0 / 2 \\
(0.278)\end{array}$ \\
\hline Investment Grade & 0.791 & $0.367 * *$ & 0.862 & 1.031 & 1.309 \\
\hline & $(0.187)$ & $(0.172)$ & $(1.593)$ & $(0.626)$ & $(0.552)$ \\
\hline $\mathrm{N}^{\circ}$ Tranches & 0.892 & 0.911 & 0.803 & 0.714 & 0.957 \\
\hline & $(0.0652)$ & $(0.0701)$ & $(0.292)$ & $(0.149)$ & $(0.104)$ \\
\hline Total Issue & $0.795^{* * *}$ & 0.999 & 0.984 & $0.390 * * *$ & $0.796^{* *}$ \\
\hline & $(0.0490)$ & $(0.0974)$ & $(0.294)$ & $(0.0693)$ & $(0.0881)$ \\
\hline First Issuer & 0.759 & 0.684 & 0.343 & 1.357 & 0.390 \\
\hline & (0.194) & $(0.220)$ & $(0.411)$ & $(0.911)$ & $(0.354)$ \\
\hline Firm Size & 1.084 & 0.955 & 0.995 & $2.002^{* * * *}$ & 0.984 \\
\hline & $(0.0624)$ & $(0.0832)$ & $(0.243)$ & $(0.376)$ & $(0.110)$ \\
\hline ROA & $0.965^{* *}$ & 0.987 & $0.892^{* *}$ & 0.940 & 0.985 \\
\hline & $(0.0157)$ & $(0.0270)$ & $(0.0498)$ & $(0.0425)$ & $(0.0316)$ \\
\hline Debt to Equity & $1.000^{* *}$ & 1.000 & $1.000 * * *$ & 1.000 & 1.000 \\
\hline & $(8.01 \mathrm{e}-06)$ & $(9.71 \mathrm{e}-06)$ & $(2.15 \mathrm{e}-05)$ & $(3.19 \mathrm{e}-05)$ & (3.04e-05) \\
\hline Syndicate Size & $0.682 * * *$ & 0.915 & 0.773 & $0.600 * * *$ & $0.603 * * *$ \\
\hline & $(0.0275)$ & $(0.0785)$ & $(0.141)$ & $(0.0606)$ & $(0.0437)$ \\
\hline Finance Vehicle & $0.717^{* *}$ & $0.556^{* *}$ & 0.637 & 0.849 & 0.677 \\
\hline & $(0.0952)$ & $(0.138)$ & $(0.315)$ & $(0.258)$ & $(0.178)$ \\
\hline INDUSTRIAL & $\begin{array}{l}1.531 * * \\
(0280)\end{array}$ & $\begin{array}{c}1.333 \\
(0.390)\end{array}$ & $\begin{array}{l}3.406^{*} \\
(2.916)\end{array}$ & $\begin{array}{c}10.89 * * * \\
(5.988)\end{array}$ & $\begin{array}{c}0.698 \\
(0248)\end{array}$ \\
\hline Year & Yes & Yes & Yes & Yes & Yes \\
\hline Countries & Yes & Yes & Yes & Yes & Yes \\
\hline Pseudo $\mathrm{R}^{2}$ & 0.1681 & 0.0922 & 0.1692 & 0.3306 & 0.1816 \\
\hline Log-Likelihood & -1560.0434 & -628.7560 & -123.9553 & -259.0286 & -462.5543 \\
\hline $\mathrm{p}$-value $\left(\mathrm{chi}^{2}\right)$ & 0.00 & 0.00 & 0.00 & 0.00 & 0.00 \\
\hline Observations & 2,848 & 1,002 & 220 & 604 & 1,022 \\
\hline
\end{tabular}




\section{TABLE XIII}

ROBUSTNESS ON THE PROBABILITY OF REPUTABLE MATCHING: SUBSAMPLES OF BANKS (ODDS RATIO)

This table presents the odds ratio and the z-statistics for the logit regressions for non-financial and banking corporate bonds issued in Europe during 2003 - 2013 . Columns I to III consider a subsample of banks hat annually issued corporate bonds but did not act as underwriter. Columns IV to VI consider a subsample of banks that annually issued corporate bonds and acted as underwriters for other issuers. Columns VII to IX consider a subsample of banks that issued corporate bonds and acted as underwriters for other issuers with an underwriter market share larger than $0.5 \%$. The dependent variable is a binary variable that takes the value 1 if the bond is placed by a reputable underwriter. Issue size is the natural logarithm of the bond proceeds. The maturity variable is the natural logarithm of bond's years to mature. Callability is a dummy for bonds with a call option. The investment grade variable is a dummy taking the value 1 for Investment Grade bonds. Number of tranches reflects the tranches forming a deal. Total issue is the natural logarithm of the sum of relative issue sizes during the sample period. First issuer is a variable taking the value 1 if the bond is the first bond issued by the issuer in the last 15 years. The variable firm size is the natural logarithm of the issuer's total assets. ROA is computed as the return on assets based on the net incomes and total assets. Debt equity is a ratio of total liabilities to total equity. Syndicate size reflects the number of deal underwriters. Finance vehicle is a variable taking the value 1 if the issuer is a finance vehicle company. The dummy variable INDUSTRIAL is a dummy taking the value 1 if the issuer is a non-bank company $* * *, * * *$ Coefficients are statistically significant different than zero at least at $10 \%, 5 \%$ and $1 \%$ levels.

\begin{tabular}{|c|c|c|c|c|c|c|c|c|c|}
\hline \multirow[b]{2}{*}{ VARIABLES } & \multicolumn{3}{|c|}{ Subsample: Pure Bank Issuers } & \multicolumn{3}{|c|}{ Subsample: Bank Issuers \& Underwriters } & \multicolumn{3}{|c|}{ Subsample: Bank Issuers \& Underwriters with market share >0.5 } \\
\hline & $2003-2013$ & Precrisis & Crisis & $2003-2013$ & Precrisis & Crisis & 2003-2013 & Precrisis & Crisis \\
\hline Issue Size & $\begin{array}{c}1.681^{* * * *} \\
(0.149)\end{array}$ & $\begin{array}{c}1.689 * * * \\
(0.202)\end{array}$ & $\begin{array}{c}1.681^{* * * *} \\
(0.216)\end{array}$ & $\begin{array}{l}1.581^{* * * *} \\
(0.0943)\end{array}$ & $\begin{array}{c}1.603 * * * * \\
(0.123)\end{array}$ & $\begin{array}{c}1.754 * * * \\
(0133)\end{array}$ & $1.562 * * *$ & $\begin{array}{c}1.579^{* * * *} \\
(0136)\end{array}$ & $\begin{array}{c}1.750^{* * * *} \\
(0145)\end{array}$ \\
\hline Maturity & $2.051^{* * * *}$ & 1.476 & $2.392^{* * * *}$ & $1.735^{* * * *}$ & $1.495^{* * * * *}$ & $1.965^{* * * *}$ & $1.745^{* * * *}$ & $1.523 * * *$ & $1.926^{* * * *}$ \\
\hline & $(0.313)$ & $(0.364)$ & $(0.493)$ & $(0.208)$ & $(0.187)$ & $(0.284)$ & $(0.200)$ & $(0.211)$ & $(0.275)$ \\
\hline Callability & 1.065 & 0.973 & 1.194 & 1.159 & 1.201 & 1.304 & 1.285 & 1.275 & $1.372 *$ \\
\hline & $(0.188)$ & $(0.315)$ & $(0.240)$ & $(0.189)$ & $(0.215)$ & $(0.224)$ & $(0.220)$ & $(0.241)$ & $(0.242)$ \\
\hline Investment Grade & 0.757 & 0.743 & 0.786 & 0.961 & 1.064 & 0.967 & 1.111 & 1.089 & 1.055 \\
\hline & $(0.183)$ & $(0.307)$ & $(0.211)$ & $(0.226)$ & $(0.258)$ & $(0.228)$ & $(0.270)$ & $(0.271)$ & $(0.255)$ \\
\hline $\mathrm{N}^{\circ}$ Tranches & 1.040 & 0.846 & 1.047 & 0.966 & 1.033 & 0.943 & 0.964 & 1.117 & 0.923 \\
\hline & $(0.102)$ & $(0.186)$ & $(0.114)$ & $(0.0596)$ & $(0.0670)$ & $(0.0739)$ & $(0.0754)$ & $(0.107)$ & $(0.0740)$ \\
\hline Total Issue & 0.936 & 1.050 & 0.832 & $0.760 * * *$ & $0.784 * * * *$ & $0.734 * * *$ & $0.687 * * *$ & $0.702 * * *$ & $0.703^{* * * *}$ \\
\hline & (0.0888) & (0.127) & (0.119) & $(0.0683)$ & $(0.0739)$ & $(0.0779)$ & $(0.0683)$ & $(0.0736)$ & $(0.0782)$ \\
\hline First Issuer & $0.712^{*}$ & 0.751 & $0.638^{*}$ & $0.567 * * *$ & $0.510 * * *$ & $0.622 * *$ & $0.547 * * *$ & $0.495^{* * * *}$ & $0.603 * *$ \\
\hline & $(0.129)$ & $(0.219)$ & $(0.162)$ & $(0.117)$ & $(0.108)$ & $(0.132)$ & $(0.119)$ & $(0.104)$ & $(0.130)$ \\
\hline Firm Size & $\begin{array}{c}1.042 \\
(0.0961)\end{array}$ & $\begin{array}{c}0.905 \\
(0.103)\end{array}$ & $\begin{array}{c}1.192 \\
(0.161)\end{array}$ & $\begin{array}{l}1.295 * * \\
(0.139)\end{array}$ & $\begin{array}{c}1.111 \\
(0.115)\end{array}$ & $\begin{array}{c}1.377 * * * * \\
(0.164)\end{array}$ & $\begin{array}{l}1.328 * * \\
(0.155)\end{array}$ & $\begin{array}{l}1.208^{*} \\
(0.131)\end{array}$ & $\begin{array}{l}1.359 \text { ** } \\
(0.163)\end{array}$ \\
\hline ROA & 0.985 & 1.003 & 0.974 & 0.972 & 0.981 & 0.969 & 0.973 & 0.981 & 0.972 \\
\hline & $(0.0162)$ & $(0.0226)$ & $(0.0189)$ & $(0.0206)$ & $(0.0166)$ & (0.0194) & (0.0199) & $(0.0166)$ & (0.0189) \\
\hline Debt to Equity & $1.000^{*}$ & 1.000 & $1.000 *$ & $1.000 * * *$ & $1.000 * * *$ & 1.000 & 1.000 & 1.000 & 1.000 \\
\hline & $\begin{array}{c}(1.18 \mathrm{e}-05) \\
0.751 * * * *\end{array}$ & $\begin{array}{c}(0.00137) \\
0.890\end{array}$ & $\begin{array}{c}(1.22 \mathrm{e}-05) \\
0.725 * * * *\end{array}$ & $\begin{array}{c}(4.37 \mathrm{e}-06) \\
0.712 * * * *\end{array}$ & $\begin{array}{c}(4.41 \mathrm{e}-06) \\
0.821 * * * *\end{array}$ & $\begin{array}{c}(1.02 \mathrm{e}-05) \\
0.675 * * *\end{array}$ & $\begin{array}{c}(1.35 \mathrm{e}-05) \\
0.716 * * *\end{array}$ & $\begin{array}{l}(0.00225) \\
0.809 * * * *\end{array}$ & $\begin{array}{l}(1.17 \mathrm{e}-05) \\
0688 * * *\end{array}$ \\
\hline Syndicate Size & $(0.0375)$ & $(0.111)$ & $(0.0394)$ & $(0.0608)$ & $(0.0510)$ & $(0.0534)$ & $(0.0585)$ & $(0.0477)$ & $(0.0540)$ \\
\hline Finance Vehicle & $\begin{array}{c}0.505 * * * \\
(0.100)\end{array}$ & $\begin{array}{c}0.412^{* * * *} \\
(0.115)\end{array}$ & $\begin{array}{l}0.538 * * \\
(0.130)\end{array}$ & $\begin{array}{c}0.659 \\
(0.168)\end{array}$ & $\begin{array}{l}0.576 * * \\
(0.132)\end{array}$ & $\begin{array}{l}0.623^{*} \\
(0.157)\end{array}$ & $\begin{array}{c}0.709 \\
(0.177)\end{array}$ & $0.603 * *$ & $0.634 *$ \\
\hline INDUSTRIAL & $1.642 * *$ & $\begin{array}{l}1.380 \\
(0.458)\end{array}$ & $2.124 * *$ & $2.360^{* * * *}$ & 1.292 & $3.332 * * *$ & $1.989^{*}$ & 1.361 & $2.722 * * *$ \\
\hline Constant & $\begin{array}{c}(0.387) \\
0.00655 * * * \\
(0.00522)\end{array}$ & $\begin{array}{c}(0.458) \\
0.0546 * * * \\
(0.0565)\end{array}$ & $\begin{array}{c}(0.752) \\
0.00310^{* * *} \\
(0.00341)\end{array}$ & $\begin{array}{c}(0.700) \\
0.00782^{* * * *} \\
(0.00684)\end{array}$ & $\begin{array}{c}(0.480) \\
0.0231 * * * \\
(0.0205)\end{array}$ & $\begin{array}{c}(1.075) \\
0.00225^{* * * *} \\
(0.00221)\end{array}$ & $\begin{array}{c}(0.725) \\
0.0131 * * * \\
(0.0133)\end{array}$ & $\begin{array}{c}(0.532) \\
0.0226^{* * *} \\
(0.0204)\end{array}$ & $\begin{array}{c}(1.016) \\
0.00347 * * * \\
(0.00355)\end{array}$ \\
\hline Year & Yes & Yes & Yes & Yes & & Yes & Yes & Yes & Yes \\
\hline Countries & Yes & Yes & Yes & Yes & Yes & Yes & Yes & Yes & Yes \\
\hline Standard Errors & Cluster Issuer & Cluster Issuer & Cluster Issuer & Cluster Issuer & Cluster Issuer & Cluster Issuer & Cluster Issuer & Cluster Issuer & Cluster Issuer \\
\hline Pseudo $\mathrm{R}^{2}$ & 0.1713 & 0.1302 & 0.1655 & 0.1959 & 0.1749 & 0.2309 & 0.2004 & 0.1797 & 0.2321 \\
\hline Log-Likelihood & -1102.7375 & -389.27226 & -699.21456 & -1594.1836 & -1066.2555 & -1267.561 & -1422.6021 & -999.81438 & -1169.8465 \\
\hline p-value $\left(\mathrm{chi}^{2}\right)$ & 0.00 & 0.00 & 0.00 & 0.00 & 0.00 & 0.00 & 0.00 & 0.00 & 0.00 \\
\hline Observations & 2,082 & 646 & 1,436 & 3,095 & 1,955 & 2,630 & 2,738 & 1,850 & 2,378 \\
\hline
\end{tabular}


TABLE XIV

ROBUSTNESS ON THE PROBABILITY OF REPUTABLE MATCHING FOR BANKING CORPORATE BONDS CONTROLLING FOR BANKS' REPUTATION (ODDS RATIO)

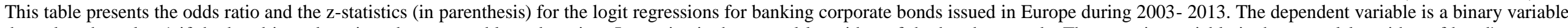

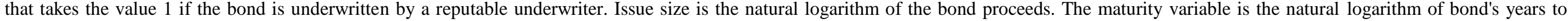

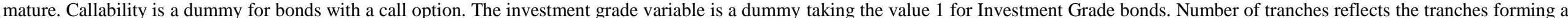

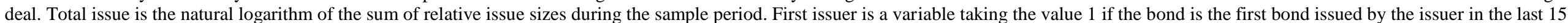

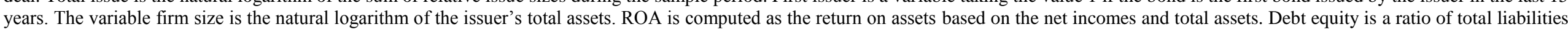

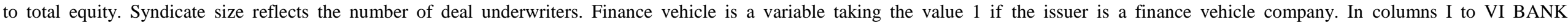

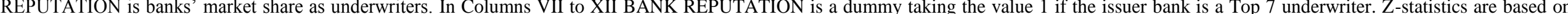
issuer clustered standard errors. A constant term (not reported) is included in all regressions. *,**,*** Coefficients are statistically significant different than zero at least at $10 \%, 5 \%$ and $1 \%$ levels

\begin{tabular}{|c|c|c|c|c|c|c|c|c|c|c|c|c|}
\hline \multirow[b]{2}{*}{ VARIABLES } & \multicolumn{6}{|c|}{ BANK REPUTATION = Bank's Underwriter Market Share } & \multicolumn{6}{|c|}{ BANK REPUTATION = Bank Top 7 Underwriter } \\
\hline & 2003-2013 & Precrisis & Crisis & $\begin{array}{c}\begin{array}{c}\text { Subprime } \\
\text { Crisis }\end{array} \\
\end{array}$ & $\begin{array}{c}\text { Banking } \\
\text { Crisis }\end{array}$ & $\begin{array}{c}\text { Sovereign } \\
\text { Crisis } \\
\end{array}$ & 2003-2013 & Precrisis & Crisis & $\begin{array}{c}\text { Subprime } \\
\text { Crisis }\end{array}$ & $\begin{array}{c}\text { Banking } \\
\text { Crisis }\end{array}$ & $\begin{array}{c}\text { Sovereign } \\
\text { Crisis } \\
\end{array}$ \\
\hline Issue Size & $\begin{array}{c}1.451 * * * \\
(0.101)\end{array}$ & $\begin{array}{c}1.430^{* * * *} \\
(0.131)\end{array}$ & $\begin{array}{c}1.499 * * * \\
(0.149)\end{array}$ & $\begin{array}{c}0.905 \\
(0.348)\end{array}$ & $\begin{array}{c}1.775^{* * * *} \\
(0.263)\end{array}$ & $\begin{array}{c}1.731^{* * * *} \\
(0.223)\end{array}$ & $\begin{array}{c}1.434 * * * \\
(0.0999)\end{array}$ & $\begin{array}{c}1.422 * * * \\
(0.132)\end{array}$ & $\begin{array}{c}1.494 * * * \\
(0.142)\end{array}$ & $\begin{array}{c}0.989 \\
(0.346)\end{array}$ & $\begin{array}{c}1.727 * * * \\
(0.250)\end{array}$ & $\begin{array}{c}1.769^{* * *} \\
(0.209)\end{array}$ \\
\hline \multirow[t]{2}{*}{ Maturity } & $1.743^{* * * *}$ & $1.488^{* * *}$ & $1.931^{* * *}$ & 0.809 & 1.165 & $2.498^{* * * *}$ & $1.878^{* * * * *}$ & $1.527^{* * * *}$ & $2.246 * * *$ & 0.760 & 1.245 & $3.032 * * *$ \\
\hline & $(0.219)$ & $(0.231)$ & $(0.335)$ & $(0.391)$ & $(0.455)$ & $(0.531)$ & $(0.240)$ & $(0.234)$ & $(0.379)$ & $(0.425)$ & $(0.564)$ & $(0.673)$ \\
\hline \multirow{2}{*}{ Callability } & $0.517 * *$ & $0.463 * *$ & 0.699 & 9.191 & 2.842 & $0.365^{* *}$ & $0.430^{* * * *}$ & $0.400^{* *}$ & 0.575 & 5.766 & 2.410 & $0.314^{* *}$ \\
\hline & $(0.141)$ & $(0.164)$ & $(0.296)$ & (13.55) & $(3.412)$ & $(0.168)$ & $(0.120)$ & $(0.147)$ & $(0.259)$ & (8.676) & (3.155) & $(0.170)$ \\
\hline \multirow[t]{2}{*}{ Investment Grade } & 0.517 & 0.675 & 0.701 & 0.341 & 1.439 & 0.657 & 0.485 & 0.596 & 0.699 & 0.366 & 1.375 & 0.715 \\
\hline & $(0.279)$ & $(0.478)$ & $(0.561)$ & $(0.654)$ & $(1.301)$ & $(0.563)$ & $(0.263)$ & $(0.422)$ & $(0.556)$ & $(0.679)$ & (1.178) & $(0.586)$ \\
\hline \multirow[t]{2}{*}{$\mathrm{N}^{\circ}$ Tranches } & $0.688^{* *}$ & 0.460 & $0.720 * *$ & 0.429 & $0.448 * * *$ & 0.786 & $0.662 * * *$ & 0.612 & $0.702 * *$ & 0.512 & 0.390 *** & 0.791 \\
\hline & $(0.102)$ & $(0.280)$ & $(0.107)$ & $(0.232)$ & $(0.137)$ & $(0.133)$ & $(0.101)$ & $(0.363)$ & $(0.108)$ & $(0.245)$ & $(0.131)$ & $(0.140)$ \\
\hline \multirow[t]{2}{*}{ Total Issue } & $0.855^{*}$ & 0.899 & $0.818^{*}$ & 0.856 & 0.707 & 0.876 & 0.877 & 0.944 & 0.826 & 0.862 & 0.739 & 0.900 \\
\hline & $(0.0732)$ & (0.0912) & $(0.0987)$ & $(0.301)$ & $(0.196)$ & $(0.121)$ & $(0.0764)$ & $(0.0891)$ & (0.0989) & $(0.329)$ & $(0.200)$ & $(0.115)$ \\
\hline \multirow{2}{*}{ First Issuer } & 0.730 & 0.755 & 0.621 & 0.297 & 1.543 & 0.256 ** & 0.746 & 0.809 & 0.654 & 0.266 & 1.572 & $0.278 * *$ \\
\hline & $(0.195)$ & $(0.313)$ & $(0.243)$ & $(0.336)$ & (1.025) & $(0.163)$ & $(0.202)$ & $(0.332)$ & $(0.250)$ & $(0.296)$ & $(0.935)$ & $(0.176)$ \\
\hline \multirow{2}{*}{ Firm Size } & 1.060 & 1.036 & 1.048 & 1.068 & 1.422 & 0.835 & 1.082 & 0.998 & 1.068 & 1.190 & 1.386 & 0.817 \\
\hline & $(0.120)$ & $(0.127)$ & $(0.165)$ & $(0.383)$ & $(0.467)$ & $(0.152)$ & $(0.122)$ & $(0.116)$ & $(0.162)$ & $(0.452)$ & $(0.445)$ & $(0.142)$ \\
\hline \multirow[t]{2}{*}{ ROA } & $1.235 \mathrm{e}+07$ & $5.889 \mathrm{e}+13$ & 3,750 & $1.154 \mathrm{e}+29$ & 0.00606 & $4.917 e+07$ & 423,307 & $6.697 e+07$ & 1,084 & $5.266 \mathrm{e}+25$ & 0.0989 & 2,872 \\
\hline & $(2.414 \mathrm{e}+08)$ & $(2.134 e+15)$ & $(72,953)$ & $(7.649 e+30)$ & $(0.0597)$ & $(1.315 e+09)$ & $(7.384 e+06)$ & $(2.153 e+09)$ & $(18,147)$ & $(3.502 \mathrm{e}+27)$ & $(1.050)$ & $(70,600)$ \\
\hline \multirow[t]{2}{*}{ Debt to Equity } & 1.000 & 1.000 & 1.000 & $1.000 * *$ & 0.998 & $1.000^{*}$ & 1.000 & $1.000^{*}$ & 1.000 & $1.000^{*}$ & 0.998 & $1.000^{*}$ \\
\hline & $(8.32 \mathrm{e}-06)$ & $(8.43 \mathrm{e}-06)$ & $(2.11 \mathrm{e}-05)$ & $(2.19 \mathrm{e}-05)$ & $(0.00144)$ & $(2.23 \mathrm{e}-05)$ & $(8.94 \mathrm{e}-06)$ & $(7.76 \mathrm{e}-06)$ & $(2.03 e-05)$ & $(2.34 \mathrm{e}-05)$ & (0.00166) & $(2.44 \mathrm{e}-05)$ \\
\hline \multirow[t]{2}{*}{ Syndicate Size } & $\begin{array}{l}0.742 * * * \\
(0.0780)\end{array}$ & 0.772 & $0.721 * * *$ & 0.797 & $0.573 * * *$ & $0.789^{* *}$ & $0.783 * *$ & 0.775 & $0.754 * * *$ & 0.844 & $0.621 * * *$ & $0.821 *$ \\
\hline & $(0.0780)$ & $(0.156)$ & $(0.0724)$ & $(0.297)$ & $(0.101)$ & $(0.0878)$ & (0.0916) & $(0.162)$ & (0.0808) & $(0.302)$ & $(0.101)$ & $(0.0975)$ \\
\hline Finance Vehicle & $\begin{array}{l}2.819^{*} \\
(1.721)\end{array}$ & $\begin{array}{l}1.280 \\
(1.317)\end{array}$ & $\begin{array}{c}3.762 * * \\
(2.291)\end{array}$ & $\begin{array}{c}21.36^{* *} \\
(30.98)\end{array}$ & $\begin{array}{c}102.9 * * * \\
(177.3)\end{array}$ & $\begin{array}{c}0.197 * * \\
(0.135)\end{array}$ & $\begin{array}{c}3.771 * * \\
(2.533)\end{array}$ & $\begin{array}{c}0.806 \\
(0.761)\end{array}$ & $\begin{array}{c}5.116 * * * \\
(3.199)\end{array}$ & $\begin{array}{c}23.68 * * \\
(32.60)\end{array}$ & $\begin{array}{c}236.7 * * * \\
(480.6)\end{array}$ & $\begin{array}{l}0.219^{*} \\
(0.176)\end{array}$ \\
\hline BANK REPUTATION & $\begin{array}{c}1.296 * * * \\
(0.0553)\end{array}$ & $\begin{array}{l}1.177 * * \\
(0.0793)\end{array}$ & $\begin{array}{l}1.343^{* * * *} \\
(0.0907)\end{array}$ & $\begin{array}{c}1.567^{* * * *} \\
(0.187)\end{array}$ & $\begin{array}{c}1.493^{* * *} \\
(0.196)\end{array}$ & $\begin{array}{c}1.390^{* * *} \\
(0.132)\end{array}$ & $\begin{array}{c}16.80^{* * * *} \\
(5.572)\end{array}$ & $\begin{array}{c}16.50^{* * * *} \\
(7.563)\end{array}$ & $\begin{array}{c}17.08 * * * * \\
(6.873)\end{array}$ & $\begin{array}{c}80.63 * * * \\
(76.91)\end{array}$ & $\begin{array}{c}42.84 * * * * \\
(32.36)\end{array}$ & $\begin{array}{c}23.90^{* * * *} \\
(10.27)\end{array}$ \\
\hline Constant & $\begin{array}{c}0.101 * * \\
(0.106)\end{array}$ & $\begin{array}{c}0.212 \\
(0.274)\end{array}$ & $\begin{array}{l}0.0899 \\
(0.143)\end{array}$ & $\begin{array}{c}5.377 \\
(20.68)\end{array}$ & $\begin{array}{c}0.00417 * * \\
(0.00972)\end{array}$ & $\begin{array}{c}0.216 \\
(0.397)\end{array}$ & $\begin{array}{c}0.0548^{* * * *} \\
(0.0574)\end{array}$ & $\begin{array}{l}0.185 \\
(0.221)\end{array}$ & $\begin{array}{l}0.0506^{*} \\
(0.0774)\end{array}$ & $\begin{array}{c}0.801 \\
(2.668)\end{array}$ & $\begin{array}{c}0.00457 * * \\
(0.0107)\end{array}$ & $\begin{array}{c}0.128 \\
(0.229)\end{array}$ \\
\hline & & & & & Yes & & Yes & Yes & Yes & & & \\
\hline \multirow{3}{*}{$\begin{array}{l}\text { Countries } \\
\text { Standard Errors }\end{array}$} & Yes & Yes & Yes & Yes & Yes & Yes & Yes & Yes & Yes & Yes & Yes & Yes \\
\hline & Cluster & Cluster & Cluster & Cluster & Cluster & Cluster & Cluster & Cluster & Cluster & Cluster & Cluster & Cluster \\
\hline & Issuer & Issuer & Issuer & Issuer & Issuer & Issuer & Issuer & Issuer & Issuer & Issuer & Issuer & Issuer \\
\hline Pseudo $\mathrm{R}^{2}$ & -1032.5641 & -458.3386 & -558.3643 & -59.126437 & -127.80534 & -312.23006 & -985.41718 & -439.2027 & -529.10941 & -55.410239 & -118.41241 & -292.26709 \\
\hline Log-Likelihood & 0.2523 & 0.1052 & 0.3305 & 0.4195 & 0.5452 & 0.2703 & 0.2864 & 0.1426 & 0.3656 & 0.4560 & 0.5786 & 0.3170 \\
\hline $\mathrm{p}$-value $\left(\mathrm{chi}^{2}\right)$ & 0.00 & 0.00 & 0.00 & 0.00 & 0.00 & 0.00 & 0.00 & 0.00 & 0.00 & 0.00 & 0.00 & 0.00 \\
\hline Observations & 2,197 & 747 & 1,450 & 147 & 525 & 778 & 2,197 & 747 & 1,450 & 147 & 525 & 778 \\
\hline
\end{tabular}


TABLE XV

ROBUSTNESS ON THE PROBABILITY OF REPUTABLE MATCHING FOR BANKING CORPORATE BONDS CONTROLLING FOR BANKS' REPUTATION AND SELF-UNDERWRITING (ODDS RATIO)

This table presents the odds ratio and the z-statistics (in parenthesis) for the logit regressions for banking corporate bonds issued in Europe during 2003- 2013. The dependent variable is a binary variable that takes the value 1 if the bond is underwritten by a reputable underwriter. Issue size is the natural logarithm of the bond proceeds. The maturity variable is the natural logarithm of bond's years to mature. Callability is a dummy for bonds with a call option. The investment grade variable is a dummy taking the value 1 for Investment Grade bonds. Number of tranches reflects the tranches forming a deal. Total issue is the natural logarithm of the sum of relative issue sizes during the sample period. First issuer is a variable taking the value 1 if the bond is the first bond issued by the issuer in the last 15 years. The variable firm size is the natural logarithm of the issuer's total assets. ROA is computed as the return on assets based on the net incomes and total assets. Debt equity is a ratio of total liabilities to total equity. Syndicate size reflects the number of deal underwriters. Finance vehicle is a variable taking the value 1 if the issuer is a finance vehicle company. In column I to VI Bank reputation is banks' market share as underwriters. In Columns VII to XII Bank Reputation is a dummy taking the value 1 if the issuer bank is a Top 7 underwriter. Self-Underwriter is a dummy that takes the value 1 if the bank has in the same year issued bonds that it has placed by itself and other bonds that have been placed by third parties. Z-statistics are based on issuer clustered standard errors. A constant term (not reported) is included in all regressions. *,**,*** Coefficients are statistically significant different than zero at least at $10 \%, 5 \%$ and $1 \%$ levels

\begin{tabular}{|c|c|c|c|c|c|c|}
\hline \multirow[b]{2}{*}{ VARIABLES } & \multicolumn{3}{|c|}{$\begin{array}{c}\text { BANK REPUTATION = Bank's } \\
\text { Underwriter Market Share }\end{array}$} & \multicolumn{3}{|c|}{$\begin{array}{c}\text { BANK REPUTATION = Bank Top } 7 \\
\text { Underwriter }\end{array}$} \\
\hline & $2003-2013$ & Precrisis & Crisis & $2003-2013$ & Precrisis & Crisis \\
\hline Issue Size & $\begin{array}{l}1.449 * * * \\
(0.101)\end{array}$ & $\begin{array}{c}1.438 * * * \\
(0.139)\end{array}$ & $\begin{array}{l}1.518 * * * \\
(0.153)\end{array}$ & $\begin{array}{l}1.432 * * * \\
(0.0991)\end{array}$ & $\begin{array}{l}1.427 * * * \\
(0.136)\end{array}$ & $\begin{array}{l}1.509 * * * \\
(0.145)\end{array}$ \\
\hline Maturity & $\begin{array}{l}1.743 * * * \\
(0.222)\end{array}$ & $\begin{array}{l}1.499 * * * \\
(0.229)\end{array}$ & $\begin{array}{l}1.892 * * * \\
(0.321)\end{array}$ & $\begin{array}{c}1.874 * * * \\
(0.241)\end{array}$ & $\begin{array}{l}1.531 * * * \\
(0.233)\end{array}$ & $\begin{array}{l}2.193 * * * \\
(0.362)\end{array}$ \\
\hline Callability & $\begin{array}{c}0.524 * * \\
(0.144)\end{array}$ & $\begin{array}{c}0.429 * * \\
(0.159)\end{array}$ & $\begin{array}{c}0.717 \\
(0.300)\end{array}$ & $\begin{array}{c}0.441 * * * \\
(0.123)\end{array}$ & $\begin{array}{c}0.382 * * \\
(0.145)\end{array}$ & $\begin{array}{c}0.585 \\
(0.257)\end{array}$ \\
\hline Investment Grade & $\begin{array}{c}0.548 \\
(0.296)\end{array}$ & $\begin{array}{c}0.639 \\
(0.469)\end{array}$ & $\begin{array}{c}0.686 \\
(0.539)\end{array}$ & $\begin{array}{c}0.504 \\
(0.272)\end{array}$ & $\begin{array}{c}0.555 \\
(0.405)\end{array}$ & $\begin{array}{c}0.678 \\
(0.528)\end{array}$ \\
\hline $\mathrm{N}^{\mathrm{o}}$ Tranches & $\begin{array}{c}0.692 * * \\
(0.101)\end{array}$ & $\begin{array}{c}0.469 \\
(0.295)\end{array}$ & $\begin{array}{c}0.725 * * \\
(0.103)\end{array}$ & $\begin{array}{c}0.668 * * * \\
(0.0988)\end{array}$ & $\begin{array}{c}0.618 \\
(0.367)\end{array}$ & $\begin{array}{c}0.706^{* *} \\
(0.103)\end{array}$ \\
\hline Total Issue & $\begin{array}{c}0.863 * \\
(0.0743)\end{array}$ & $\begin{array}{c}0.895 \\
(0.0899)\end{array}$ & $\begin{array}{c}0.819^{*} \\
(0.0977)\end{array}$ & $\begin{array}{c}0.882 \\
(0.0773)\end{array}$ & $\begin{array}{c}0.937 \\
(0.0885)\end{array}$ & $\begin{array}{c}0.823 \\
(0.0976)\end{array}$ \\
\hline First Issuer & $\begin{array}{c}0.710 \\
(0.190)\end{array}$ & $\begin{array}{c}0.785 \\
(0.329)\end{array}$ & $\begin{array}{c}0.593 \\
(0.232)\end{array}$ & $\begin{array}{c}0.720 \\
(0.196)\end{array}$ & $\begin{array}{c}0.843 \\
(0.352)\end{array}$ & $\begin{array}{c}0.621 \\
(0.240)\end{array}$ \\
\hline Firm Size & $\begin{array}{c}1.045 \\
(0.119)\end{array}$ & $\begin{array}{c}1.041 \\
(0.129)\end{array}$ & $\begin{array}{c}1.054 \\
(0.165)\end{array}$ & $\begin{array}{c}1.075 \\
(0.122)\end{array}$ & $\begin{array}{c}1.014 \\
(0.119)\end{array}$ & $\begin{array}{c}1.084 \\
(0.166)\end{array}$ \\
\hline ROA & $\begin{array}{c}7.931 \mathrm{e}+06 \\
(1.518 \mathrm{e}+08)\end{array}$ & $\begin{array}{c}2.422 \mathrm{e}+13 \\
(8.669 \mathrm{e}+14)\end{array}$ & $\begin{array}{c}7,176 \\
(138,516)\end{array}$ & $\begin{array}{c}581,399 \\
(1.009 \mathrm{e}+07)\end{array}$ & $\begin{array}{c}2.210 \mathrm{e}+08 \\
(7.179 \mathrm{e}+09)\end{array}$ & $\begin{array}{c}3,198 \\
(54,077)\end{array}$ \\
\hline Debt to Equity & $\begin{array}{c}1.000 \\
(8.41 \mathrm{e}-06)\end{array}$ & $\begin{array}{c}1.000 * \\
(8.03 \mathrm{e}-06)\end{array}$ & $\begin{array}{c}1.000 \\
(1.93 \mathrm{e}-05)\end{array}$ & $\begin{array}{c}1.000 \\
(8.97 \mathrm{e}-06)\end{array}$ & $\begin{array}{c}1.000 * * \\
(7.98 \mathrm{e}-06)\end{array}$ & $\begin{array}{c}1.000 \\
(1.88 \mathrm{e}-05)\end{array}$ \\
\hline Syndicate Size & $\begin{array}{c}0.745 * * * \\
(0.0790)\end{array}$ & $\begin{array}{c}0.776 \\
(0.160)\end{array}$ & $\begin{array}{c}0.719 * * * \\
(0.0720)\end{array}$ & $\begin{array}{l}0.784 * * \\
(0.0916)\end{array}$ & $\begin{array}{c}0.779 \\
(0.161)\end{array}$ & $\begin{array}{l}0.752 * * * \\
(0.0807)\end{array}$ \\
\hline Finance Vehicle & $\begin{array}{l}2.844 * \\
(1.761)\end{array}$ & $\begin{array}{c}1.100 \\
(1.056)\end{array}$ & $\begin{array}{l}3.907 * * \\
(2.432)\end{array}$ & $\begin{array}{l}3.725^{*} \\
(2.519)\end{array}$ & $\begin{array}{c}0.753 \\
(0.727)\end{array}$ & $\begin{array}{c}5.143 * * * \\
(3.260)\end{array}$ \\
\hline Self Underwriter & $\begin{array}{c}0.720 \\
(0.264)\end{array}$ & $\begin{array}{c}1.119 \\
(0.582)\end{array}$ & $\begin{array}{c}0.470 \\
(0.250)\end{array}$ & $\begin{array}{c}0.759 \\
(0.220)\end{array}$ & $\begin{array}{c}1.197 \\
(0.533)\end{array}$ & $\begin{array}{c}0.589 \\
(0.222)\end{array}$ \\
\hline Bank Reputation & $\begin{array}{l}1.268 * * * \\
(0.0521)\end{array}$ & $\begin{array}{l}1.155^{* *} \\
(0.0832)\end{array}$ & $\begin{array}{l}1.301 \text { **** } \\
(0.0854)\end{array}$ & $\begin{array}{c}14.35 * * * \\
(4.493)\end{array}$ & $\begin{array}{c}12.69 * * * \\
(6.413)\end{array}$ & $\begin{array}{c}14.05 * * * \\
(5.103)\end{array}$ \\
\hline Self-Underwriter*Bank Reputation & $\begin{array}{c}1.122 \\
(0.0992)\end{array}$ & $\begin{array}{c}1.174 \\
(0.173)\end{array}$ & $\begin{array}{c}1.187 \\
(0.133)\end{array}$ & $\begin{array}{c}1.904 \\
(1.287)\end{array}$ & $\begin{array}{c}2.670 \\
(3.555)\end{array}$ & $\begin{array}{c}2.388 \\
(1.436)\end{array}$ \\
\hline Constant & $\begin{array}{c}0.109 * * \\
(0.114)\end{array}$ & $\begin{array}{c}0.204 \\
(0.264)\end{array}$ & $\begin{array}{l}0.0875 \\
(0.138)\end{array}$ & $\begin{array}{c}0.0565 * * * \\
(0.0587)\end{array}$ & $\begin{array}{c}0.163 \\
(0.199)\end{array}$ & $\begin{array}{c}0.0459^{* *} * \\
(0.0699)\end{array}$ \\
\hline $\begin{array}{l}\text { Year } \\
\text { Countries } \\
\text { Standard Errors }\end{array}$ & $\begin{array}{c}\text { Yes } \\
\text { Yes } \\
\text { Cluster } \\
\text { Issuer }\end{array}$ & $\begin{array}{c}\text { Yes } \\
\text { Yes } \\
\text { Cluster } \\
\text { Issuer }\end{array}$ & $\begin{array}{c}\text { Yes } \\
\text { Yes } \\
\text { Cluster } \\
\text { Issuer }\end{array}$ & $\begin{array}{c}\text { Yes } \\
\text { Yes } \\
\text { Cluster } \\
\text { Issuer }\end{array}$ & $\begin{array}{c}\text { Yes } \\
\text { Yes } \\
\text { Cluster } \\
\text { Issuer }\end{array}$ & $\begin{array}{c}\text { Yes } \\
\text { Yes } \\
\text { Cluster } \\
\text { Issuer }\end{array}$ \\
\hline $\begin{array}{l}\text { Pseudo R }{ }^{2} \\
\text { Log-Likelihood } \\
\text { p-value }\left(\mathrm{chi}^{2)}\right) \\
\text { Observations }\end{array}$ & $\begin{array}{c}-1030.6916 \\
0.2536 \\
0.00 \\
2,197 \\
\end{array}$ & $\begin{array}{c}-456.72589 \\
0.1083 \\
0.00 \\
747 \\
\end{array}$ & $\begin{array}{c}-555.42851 \\
0.3341 \\
0.00 \\
1,450 \\
\end{array}$ & $\begin{array}{c}-984.06654 \\
0.2874 \\
0.00 \\
2,197 \\
\end{array}$ & $\begin{array}{c}-438.47717 \\
0.1440 \\
0.00 \\
747 \\
\end{array}$ & $\begin{array}{c}-527.01242 \\
0.3681 \\
0.00 \\
1,450 \\
\end{array}$ \\
\hline
\end{tabular}




\section{ROBUSTNESS ON THE PROBABILITY OF REPUTABLE MATCHING (PRECRISIS vs. CRISIS): EXTRA CONTROLS (ODDS RATIO)}

This table presents the odds ratio and the z-statistics for the logit regressions for corporate bond issued in Europe during 2003 - 2013 including extra control variables. The dependent variable is a binary variable that takes the value 1 if the bond is placed by a reputable underwriter.

Robustness variables: Floated coupon is a dummy that takes the value 1 if the bond presents a floated coupon based on an index (e.g. Libor or Euribor). Currencies are dummies taking the value 1 if the whole deal has been issued in euros $(€)$, pounds $(£)$, American dollars $(\$)$ or in other currencies according to the specific currency-dummy. SEC is a dummy that takes the value 1 if the bond is totally sold in the USA under SEC Rule. Rule 144A is a dummy that takes the value 1 if the bond is totally US marketed via 144A. Simultaneity is a continuous variable built adding all proceeds issued in a time-window of 30 days considering the central point the issue date. A constant term (not reported) is included in all regressions. Z-statistics are based on clustered issuer standard errors. *, **, *** Coefficients are statistically significant different than zero at least at $10 \%, 5 \%$ and $1 \%$ levels.

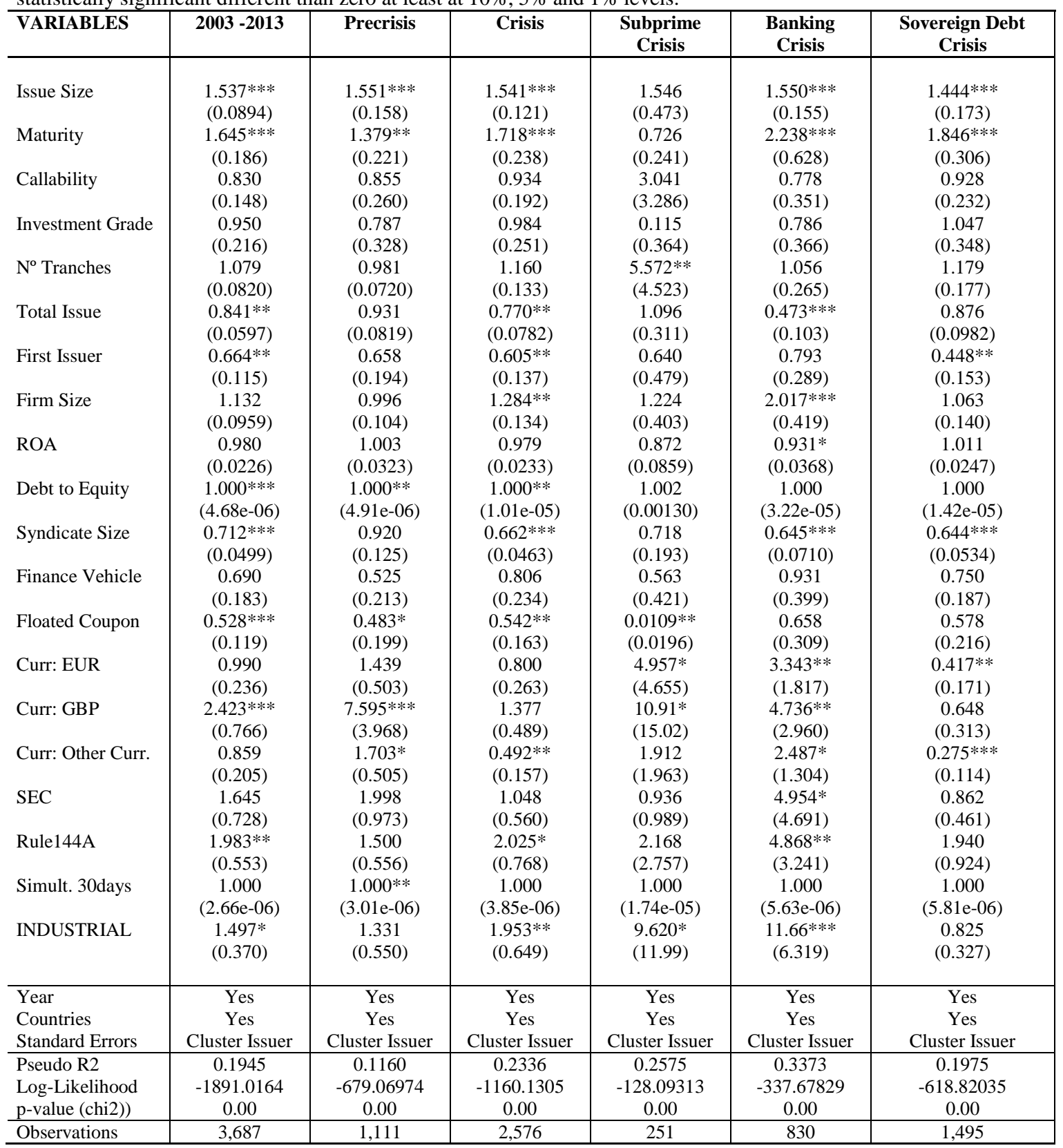




\section{TABLE XVII}

\section{ROBUSTNESS ON THE PROBABILITY OF REPUTABLE MATCHING: NON-FINANCIAL AND}

\section{BANKING CORPORATE BONDS}

This table presents the logit coefficients and the z-statistics (in parenthesis) for the logit regressions for nonfinancial and banking corporate bonds issued in Europe during 2003 - 2013. The dependent variable is a binary variable that takes the value 1 if the bond is placed by a reputable underwriter.

Robustness variables: Past issuer is a dummy that takes the value 1 if the issuer has issued corporate bonds at least once 15 years prior to the start of the sample period (from 1988 to 2003). Floated coupon is a dummy that takes the value 1 if the bond presents a floated coupon based on an index (e.g. Libor or Euribor). Currencies are dummies taking the value 1 if the whole deal has been issued in euros $(€)$, pounds $(£)$, American dollars $(\$)$ or in other currencies according to the specific currency-dummy. SEC is a dummy that takes the value 1 if the bond is totally sold in the USA under SEC Rule. Rule 144A is a dummy that takes the value 1 if the bond is totally US marketed via 144A. Public Bank issuer is a dummy that takes the value 1 if the issuer is not a sector private bank. Self\&NotSelf is a dummy that takes the value 1 if the bank has in the same year issued bonds that it has placed by itself and other bonds that have been placed by third parties Simultaneity variables are continuous variables built adding all proceeds issued in a time-window considering the central point the issue date. The time-window comprises days before and after the issue date; a 90 days-window covers all proceeds issued 45 days before and 45 days after the issue date without including the specific proceeds of the deal we are considering. A constant term (not reported) is included in all regressions. Z-statistics are based on clustered issuer standard errors. *, **, *** Coefficients are statistically significant different than zero at least at $10 \%, 5 \%$ and $1 \%$ levels.

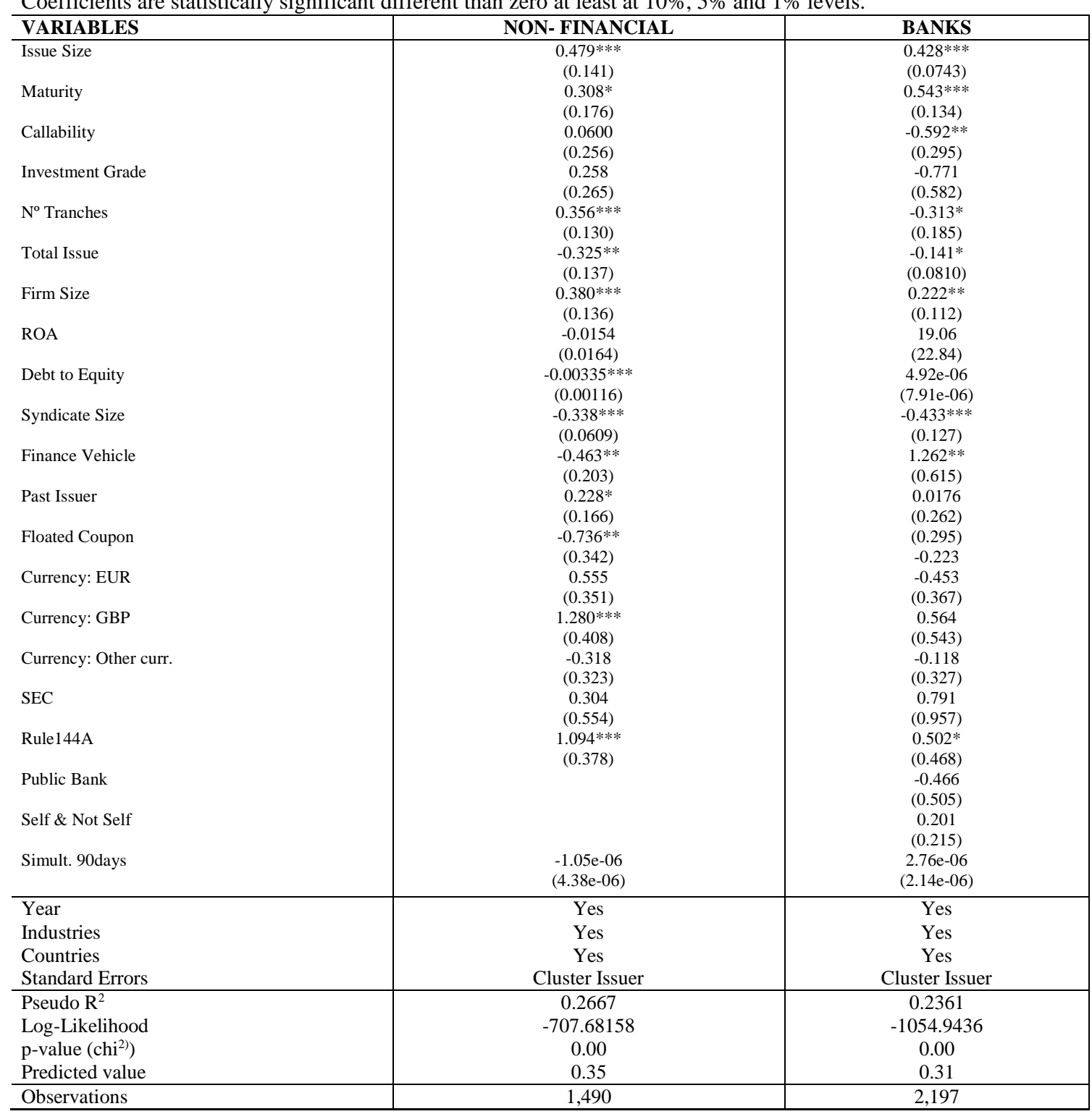

